\title{
Use of Typha angustifolia L. as Biosorbent to Remove Chloramphenicol in Aqueous Samples
}

\author{
Paula C. Pasta, Adrielli C. P. da Silva, Alexandre O. Jorgetto, Margarida J. Saeki, \\ Valber de A. Pedrosa, Marco A. U. Martines, José F. Schneider, Igor O. Minatel, \\ Joseane Rabelo, Renata S.D. Castro, Gustavo R. de Castro
}

\section{ABSTRACT}

The identification and quantification of different contaminants in natural waters have been widely disseminated in scientific journals. In the last two decades, removal from aqueous samples of drugs and their metabolites, also called emerging contaminants, have been highlighted. The problem of their existence in the environment, besides its persistence, is related to the occurrence of more resistant bacteria, being a serious risk to health. Thus, the objectives of this project were characterization of cattail leaves, Typha angustifolia $L$. in natura, and its application for the removal of the antibiotic chloramphenicol in aqueous samples. The material was characterized by Fourier Transform in the Infrared Region (FTIR), Point of Zero Charge (PZC), Nuclear Magnetic Resonance (NMR), Scanning Electron Microscopy (SEM), as well as surface area measurements (Brunauer, Emmett, Teller-BET). Batch experiments were performed considering the influence of $\mathrm{pH}$, contact time and analyte concentration, whose supernatant solution was quantified by Ultra Performance Liquid Chromatography (UPLC). Both results, regarding FTIR spectrum and NMR analysis, corroborated by identifying functional chemical groups that promote interaction between biosorbent and analyte. The pHpzc, estimated around 5.75, was considered to choose the ideal $\mathrm{pH}$ of the medium that favors adsorption. By means of SEM images, the material was characterized by parallel plates with large number of channels (heterogeneous surface). Type II isotherm was obtained from BET method, with low surface area, nonporous or macroporous, mono and multilayer adsorption. Pseudo-second order was the model that best fit the adsorption kinetics, while for determining the maximum capacity, the Freundlich model showed the highest agreement.

Keywords: Antibiotic adsorption, Bioremediation; Environmental Biotechnology, Taboa.
Published Online: February 26, 2022

ISSN: $2684-4478$

DOI: $10.24018 /$ ejchem.2022.3.1.66

\section{P. C. Pasta}

Department of Chemical and Biological Sciences, São Paulo State University (UNESP), Botucatu, SP, Brazil.

(e-mail: chiachia.pasta ${ }^{\circledR}$ unesp.br)

A. C. P. Silva

Department of Chemical and Biological Sciences, São Paulo State University (UNESP), Botucatu, SP, Brazil.

(e-mail: adriellicristina ${ }^{@}$ hotmail.com) A. O. Jorgetto

Department of Physical Chemistry, State University of São Paulo (UNESP), Araraquara, SP, Brazil.

(e-mail: xjorgetto ${ }^{@}$ gmail.com)

M. J. Saeki

Department of Chemical and Biological Sciences, São Paulo State University (UNESP), Botucatu, SP, Brazil.

(e-mail mj.saeki@unesp.br)

V. de A. Pedrosa

Department of Chemical and Biological Sciences, São Paulo State University (UNESP), Botucatu, SP, Brazil.

(e-mail: valber.pedrosa@unesp.br)

M. A. U. Martines

Department of Chemistry, Federal University of Mato Grosso do Sul (UFMS), Campo Grande, MS, Brazil.

(e-mail: marcomartines ${ }^{\circledR}$ gmail.com)

J. F. Schneider

Department of Physics and Interdisciplinary Science, University of São Paulo (USP), São Carlos, SP, Brazil.

(e-mail: schnei ${ }^{\circledR}$ ifsc.usp.br)

I. O. Minatel

Departamento de Ciências da Saúde/ UniFSP (Centro Universitário Sudoeste Paulista), Brazil.

(e-mail: igorminatel ${ }^{\circledR}$ hotmail.com)

J. Rabelo

(e-mail: josyrabb ${ }^{\circledR}$ gmail.com)

R. S. D. de Castro

Faculty of Agronomic Sciences, São

Paulo State University (UNESP), Botucatu, SP, Brazil.

(e-mail: renatadiniz1234@ ${ }^{@}$ gmail.com) Gustavo R. de Castro*

Department of Chemical and Biological Sciences, São Paulo State University (UNESP), Botucatu, SP, Brazil.

(e-mail: gustavo.castro ${ }^{\circledR}$ unesp.br)

*Corresponding Author 


\section{INTRODUCTION}

\section{A. Contamination of Water Resources and Environmental Impacts}

Natural water resources have been depositories of a variety of by-products, derived from human activities [1], [2]. Among these emerging contaminants, such as, metals, organic residues, among others, drugs represent a recent concern, as they affect the quality of water resources, and the effectiveness of water treatment to remove them from the aqueous medium. According to reference [3], such contaminants can be classified according to their chemical class, type of use (industrial or domestic), effect, source and exposure. Thus, numerous substances fall into the class of emerging contaminants, such as: pharmaceutical and personal hygiene products (PPHPs), repellents, products of veterinary origin, endocrine disruptors, drugs, surfactants, water disinfection products, additives, antibiotics, pesticides, caffeine, industrial products, beauty and cleaning products, hormones and steroids etc. [4], [5].

In some developed countries such as the United States, contamination of the environment by toxic substances is not the result of industrial activities alone. Approximately $1 \%$ of the total waste generated comes from universities, schools and research institutes [6]. Regardless of the emission sources, water and/or soil are the final destinations of almost all toxic substances released by human activities [7], [8]. According to an estimate by the Agência Nacional de Vigilância Sanitária (ANVISA) in reference [9], in Brazil, for example, $20 \%$ of all pharmaceutical production ends up being discarded in the common garbage. The index is basically formed by the inappropriate disposal of leftovers of 30 drugs expired in homes. However, in addition to improper disposal, urban sewage is also composed of residual drugs eliminated during excretion, which end up contaminating the environment [10]. Currently, both in Brazilian and international legislation, there is no regulation for the control of drug residues in water for human consumption. This is because the concentration of drugs found in drinking water is generally low, in the range of $\mu \mathrm{g} \cdot \mathrm{L}^{-1}$ to $\mathrm{ng} \cdot \mathrm{L}^{-1}$, and also because there is a lack of knowledge about the degree of acute and mainly chronic toxicity of these compounds to human health [11]. In Fig. 1, the possible ways in which they are disposed of in the environment are described.

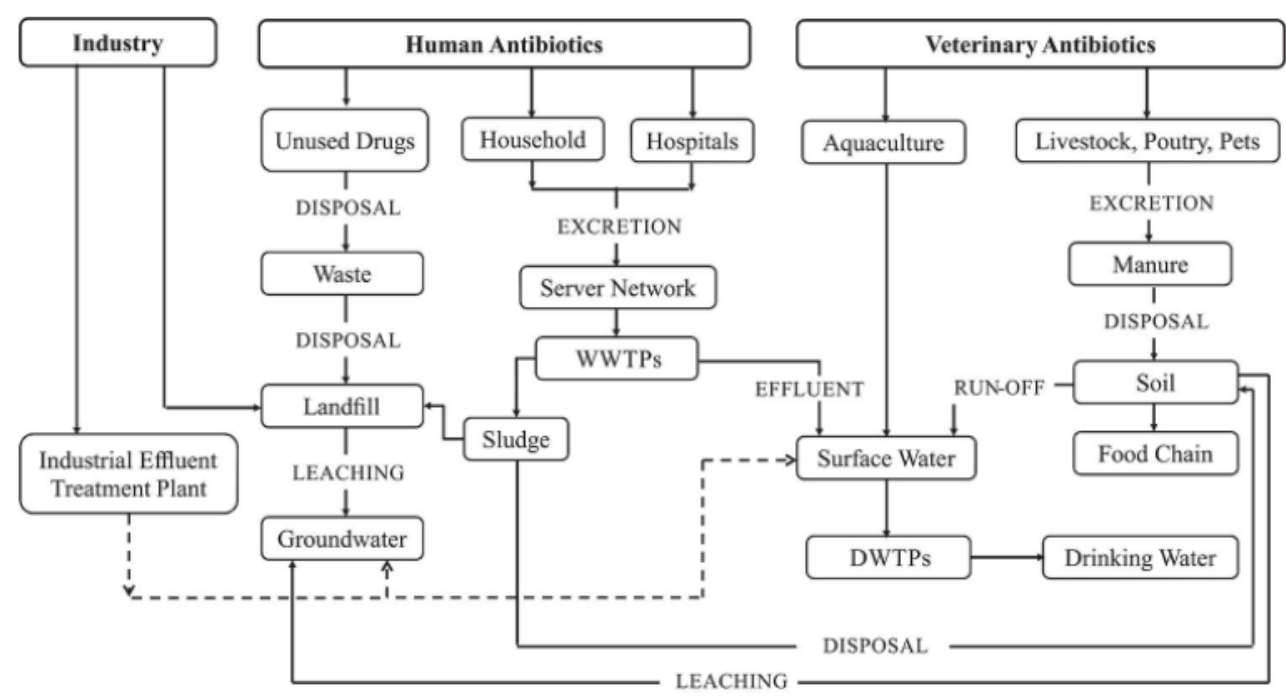

Fig. 1. Routes of environmental exposure of residual drugs (Source: Adapted from [12]).

From Fig. 1, it can be seen that medicines used in human medicine will reach sewage networks, through household and hospital effluents, even contaminating underground waters and surface waters. The presence of these compounds in groundwater may be due to various sources, such as leaching from landfills, residues from the pharmaceutical industries, or sludge from agricultural activity [13].

Fig. 1 also shows the routes originated by the pharmaceutical industries with disposal in landfills, contaminating the subsoil waters in the vicinity of the landfill [12]. However, these residues are subject to greater inspection, and usually must be treated differently in effluent stations in accordance with current legislation [14]. Thus, the main sites of environmental occurrence of residual drugs can be divided into five fundamental groups: (1) Groundwater: by infiltration of sewage or effluent lines; (2) Surface water: through the discharge of domestic, hospital, industrial or rural sewage when transported from the ground with the aid of rain; (3) Oceans: through the discharge of sewers or contaminated rivers; (4) Sediments: by deposition of insoluble active species; (5) Soil: due to inadequate urban eviction or rural use [14], [15].

When dealing specifically with Sewage Treatment Plants (STPs), these have the main purpose of eliminating the organic matter present in water resources, using aerobic and anaerobic systems, to meet the 
specific legislation of each country, in relation to their disposal or reuse. In Brazil, the effluent treatment must follow the Conselho Nacional do Meio Ambiente (CONAMA) No. 430 (update) [16]. There are a variety of methods and processes for treating contaminants in water, which can be classified into three main groups: physical, chemical and biological treatments.

Analyzing the current facts, water quality represents one of the most relevant topics in environmental analytical chemistry. Its characterization consists of the identification and quantification of different species (organic and inorganic), among which, the class of drugs has a special interest, since studies carried out in several countries have already verified the presence of these substances and their metabolites in surface, underground and supply waters. Its occurrence is also related to the emergence of bacteria resistant to certain antibiotics [17]. In STPs, the treatment depends on the characteristics of the sewage and the processes involved, so often substances such as drugs, hormones and their metabolites are not degraded, which explains their occurrence in natural waters. This also influences the limitation of STPs, which discharge their effluents into a receiving body, which can also be used to capture water and pose a risk to the population [18], [19].

The interest that the scientific community has shown regarding drugs is due to their possible interactions with biological systems, and their occurrence in different environmental compartments. Therefore, it becomes relevant to deepen the theme, not only conceptually, but also by specifying its role in the ecosystem, implications of its use too much in society and already existing regulations.

\section{B. Drugs}

Drugs are chemical substances that can be designated as micro pollutants, since they present themselves in the aquatic environment in very variable concentrations, ranging from $\mathrm{ng} \cdot \mathrm{L}^{-1}$ to $\mu \mathrm{g} \cdot \mathrm{L}^{-1}[20]$. Antibiotics stand out for their importance, as they are substances that interact with microorganisms that cause infections in the body; in addition to keeping diseases under control, or, as yet, preventing them [21]. In the human body, distribution and elimination processes result in the removal of substances in the blood, comprising the stages of metabolism and excretion of drugs in their active form through urine [22]. As found in the studies by reference [23], in the case of human medicine, the antibiotics used enter the environment, through hospital effluents and municipal wastewater.

Amphenicols make up a class of bacteriostatic antibiotics that inhibit the synthesis of bacterial polypeptides. This group includes chloramphenicol, thiamphenicol and florfenicol. Chloramphenicol was originally isolated from Streptomyces venezuelae in 1948, but it can also be obtained by laboratory synthesis [24]. The compound chloramphenicol, D-(-)-treo-2,2-dichloro-N-[ $\beta$-hydroxy $\alpha$ - (hydroxymethyl)-pnitrophenyl], of molar mass $323.1325 \mathrm{~g} \cdot \mathrm{mol}^{-1}$, molecular formula $\mathrm{C}_{11} \mathrm{H}_{12} \mathrm{Cl}_{2} \mathrm{~N}_{2} \mathrm{O}_{5}$ and pKa 5.5 [25], is an antimicrobial that acts as a broad-spectrum agent against several types of gram-positive and gram-negative organisms.

Since the 1950s, chloramphenicol has been used considerably in the treatment of domestic animals and in human medicine, due to its low cost, high efficiency and easy availability [26], [27]. Several studies reveal that this antibiotic has been found in the waters and effluents of different countries in the world [28][33]. Average concentrations of the drug in the order of 2.08 and $26.6 \mu \mathrm{g} \cdot \mathrm{L}^{-1}$ have been found in effluents from STP in China [30], [32]. Possible toxic effects triggered by its presence in aquatic environments have been evaluated in humans, such as reticulocytopenia (which can progress to anemia), granulocytopenia, thrombocytopenia, bone marrow depression (more serious case, fatal aplastic anemia) and the syndrome of gray baby [34], [35]. Because of this, the use of such a drug in food-producing animals has been banned in many countries, including the European Union [36]. Currently it is used almost exclusively as an ophthalmic medicine [37], [38].

According to its structure, this compound has physical-chemical behavior similar to some types of pesticides, because it is lipophilic, able to cross membranes, and because it is difficult to break down. Such a compound has as its final destination the soil and / or water compartments, being often found without any change in its structure or accompanied by its degradation products [20].

ANVISA Resolution No. 306/04 regulates the management of health service waste, being classified into five groups: group A (potentially infectious), group B (chemicals), group C (radioactive waste), group D (common waste), group E (sharps) [39]. They fall into group B (chemical residues): (B1) - Residues of medicines or pharmaceutical inputs when expired, contaminated, seized for disposal, partially used and other medicines unfit for consumption, which pose a risk. Included in this group [40]: hormonal products for systemic use; hormonal products for topical use, when discarded by health services, pharmacies, drugstores and medicine distributors; antibacterial products for systemic use; topical antibacterial products, when discarded by health services, pharmacies, drugstores and medicine distributors; cytostatic drugs; antineoplastic drugs; digitalis medications; immunosuppressive drugs; immunomodulatory drugs; antiretroviral drugs.

Providing more numerical information, Table I summarizes some of the main classes of substances found in aqueous media. 
TABLE I: AVERAGE DRUG CONCENTRATIONS Found In AQUEOUS MATRICES

\begin{tabular}{|c|c|c|c|c|}
\hline Substances & $\begin{array}{l}\text { Classes of } \\
\text { substances }\end{array}$ & $\begin{array}{c}\text { Average concentrations } \\
\left(\mu \mathrm{g} \cdot \mathrm{L}^{-1}\right)\end{array}$ & Matrices & References \\
\hline Ciprofloxacin & Antibiotic & 0.02 & Natural water / USA & [41] \\
\hline Chloramphenicol & Antibiotic & 0.1123 & Natural water / China & [42] \\
\hline Chloramphenicol & Antibiotic & $1.73-2.43$ & Domestic sewage / China & [30] \\
\hline Tetracycline & Antibiotic & $1.02-4.2$ & Surface water / Germany & [43] \\
\hline Estrone & Hormone & $0.02-0.05$ & Surface water / Brazil & [44] \\
\hline Estrone & Hormone & 0.04 & Domestic sewage / Brazil & [44] \\
\hline Testosterone & Hormone & 0.016 & Natural water / USA & [41] \\
\hline Clofibric Acid & $\begin{array}{l}\text { Antilipemic } \\
\text { metabolite }\end{array}$ & $0.02-0.03$ & Surface water / Brazil & [45] \\
\hline Clofibric Acid & $\begin{array}{l}\text { Antilipemic } \\
\text { metabolite }\end{array}$ & 1.0 & Domestic sewage / Brazil & [45] \\
\hline
\end{tabular}

Such substances, as well as their concentrations $\left(\mu \mathrm{g} \cdot \mathrm{L}^{-1}\right)$, represent a relevant issue regarding the contamination of water resources not only nationally, but also worldwide.

\section{Methods Used in the Determination of Drugs}

There is still no method accepted worldwide for the determination of drugs and their metabolites in aquatic environments (Table II). Many of these substances have polar functional groups and/or are thermally labile. Therefore, for its determination, techniques such as liquid and gas chromatography coupled to mass spectrometer (LC/MS, GC/MS), spectrometer with selective tandem mass detector (LC/MS/MS, GC/MS/MS) are used and spectrophotometric detector (LC/UV-Vis) [46]-[48]. The choice of technique is based on the physical-chemical characteristics of the analyte [49], [50].

TABLE II: DifFERENT METHOdS AND MATERIALS USED TO ADSORB CHLORAMPHENICOL AND THEIR RESPECTIVE RESUlTS

\begin{tabular}{lcccc}
\hline \multicolumn{1}{c}{ Materials and techniques } & Degradation & $\mathrm{q}_{\mathrm{e}}\left(\mathrm{mg} \cdot \mathrm{g}^{-1}\right)$ & Recovery $(\%)$ & References \\
\hline Wheat straw hydrogel with copper nanocomposite & 90,59 & - & - & 51 \\
Foto-Fenton Process & 88 & - & - & 52 \\
Activated carbon (eucalyptus biomass) & - & 9,81 & - & 53 \\
Organic, ionic and magnetic liquid & - & - & $94,6-99,72$ & 54 \\
\hline
\end{tabular}

Another important factor in determining these substances in low concentrations is sample preparation. Thus, in many cases, a preconcentration step that precedes the determination is necessary to reach the limit of quantification of the method. Thus, for this project, the Ultra Performance Liquid Chromatography (UPLC) system was chosen due to the know-how already established by the group and employees of the Department of Chemistry and Biochemistry at the Institute of Biosciences in São Paulo State University (UNESP), as well as lower cost when compared to coupled systems, in addition to presenting high resolution of the results generated in the chromatograms.

Thus, due to the limited removal of antimicrobial agents by Water Treatment Plants (WTPs) through traditional coagulation and sedimentation processes, various physical or chemical methods, namely disinfection processes such as ozonation, chlorination, filtration through membranes or advanced oxidative processes (AOPs) [19], [50], have been developed with the objective of removing such substances. In addition to the methods mentioned above, adsorption stands out for being a very efficient technique in the removal of these agents, since a biosorbent can be used as an alternative adsorbent because it has considerable adsorption capacity and a more affordable cost, as well as the advantage of not generate waste, since the adsorbent material used can be in natura.

\section{Adsorption}

Adsorption consists of a mass transfer process, analyzing the ability of certain solids to concentrate certain substances in liquid or gaseous fluids on their surface, thus allowing the separation of other components of these fluids [55]. The larger the outer surface per unit of solid mass, the more favorable the adsorption will be, since the adsorbed components are concentrated on the outer surface. Because of this, solid adsorbents that consist of porous particles are generally used [56].

The adsorption separation processes are based on three distinct mechanisms: as for the steric mechanism, the pores of the adsorbent material have characteristic dimensions, which allow certain molecules to enter, excluding the others; for the equilibrium mechanisms, there are the abilities of the different solids to accommodate different species of adsorbates, which are preferentially adsorbed to other compounds; the kinetic mechanism is based on the different diffusivities of the different species in the adsorbent pores [57].

The adsorption kinetics can be conducted by different processes [55],[58]: A. External mass transfer: transfer of molecules from the fluid phase to the surface of the adsorbent particle; B. Diffusion in the pore: diffusion of molecules into the pores; C. Diffusion on the surface: diffusion of molecules totally adsorbed along the surface of the pore.

In the same way, it is important to consider the processes of physisorption and chemisorption, depending on the nature of the forces involved. In the case of physical adsorption, the bonding of the adsorbent to the 
surface of the adsorbent involves a relatively weak interaction that can be attributed to the forces of Van der Waalls, and the energy released by the system is small, such as the order of magnitude of a condensation. In contrast, chemisorption involves the exchange or sharing of electrons between the molecules of the adsorbent and the surface of the adsorbent, resulting in a chemical reaction. In practice, this criterion is not absolute, although the trend is that the greater the energy released, the greater the propensity to form chemical bonds between adsorbent - adsorbate. This essentially results in a new chemical bond and, therefore, much stronger than in the case of physical activity [55].

The concepts of chemisorption and physisorption are different, however the two adsorption mechanisms are not completely independent. The distinction as to whether the species is physically or chemically adsorbed is not very clear [59], as both processes can often be described in terms of the principles of physical adsorption. In general, the differences between physical adsorption and chemical adsorption can be summarized as: physical adsorption is nonspecific, while chemical adsorption is highly specific and not all solid surfaces have active sites capable of chemically adsorbing the adsorbate. It should be noted that not all molecules present in the fluid can be chemically adsorbed, only those capable of binding to the active site [55].

\section{E. Adsorbents and Biosorbents with Potential for Drug Removal}

Several sorbent materials are used in the solid phase extraction technique, which can be natural or synthetic materials, and the choice of solid support depends on the nature of the analyte of interest and the matrix in which it is found. Some examples, such as cellulose, chitin and silica, are materials widely used as solid support [60]. Cellulose has mechanical and chemical stability, in addition to the existence of numerous hydroxyl groups ( $-\mathrm{OH}$ free per glycosidic unit) in its structure, which are sensitive to chemical modifications in order to increase the sorption capacity of metal ions [61].

The adsorbents must have adequate characteristics, such as high selectivity, high surface area, high adsorption capacity, good regeneration capacity, long life and low cost [62].

In addition to activated carbon, which is the adsorbent usually used in the treatment of wastewater and public water supplies, other adsorbents have a potential application in the removal of pharmacological compounds, such as clays, organo-modified silica gels [63], polymers such as poly (ethylene terephthalate) and residues from agro-industrial production, such as sugarcane bagasse [64].

Biosorbents are characterized by their high capacity to remove contaminants in effluents and high availability at a relatively low cost (available in nature, or are by-products of agricultural and industrial activities) and, depending on the volume produced, they represent an environmental problem, as is the case of rice and coconut husks [65]. Cashew bagasse [66], derived from wood or cellulose (seed, tree bark, sawdust) [67],[68], chitosan [69], Neem leaves [65], fungal biomass [70] are some examples of low cost biosorbents that have been investigated on a laboratory scale for the treatment of colored effluents, showing different degrees of efficiency.

Typha angustifolia L., is a perennial herbaceous plant belonging to the Typhaceae family, and is also popularly known as cattail in Brazil. Plants of this genus are common worldwide, as they grow in a freshwater environment, and consequently, are found in humid areas such as, for example, on the banks of streams, rivers and lakes [71]. The plants, originally from South America, are currently found 42 spread throughout the planet, and their leaves can reach more than 3 meters in height [72].

One of the characteristics of T. angustifolia is its internal structure, which in addition to being thick, has a shape similar to a sponge, due to the presence of air channels [73].

According to reference [74], T. angustifolia presents good results in the treatment of sewage due to its nutrient absorption capacity. In addition to this application, high values of adsorption of emerging contaminants were also found, using the powder generated from the leaves of T. angustifolia L., according to reference [75]. Thus, the availability of obtaining and its structure make T. angustifolia a promising biosorbent.

Therefore, the main objective of this study was to characterize the leaves of T. angustifolia in natura as a biosorbent potential to analyze the efficiency in the removal of antimicrobials from aqueous matrices through batch experiments, involving the study of the influence of $\mathrm{pH}$, kinetics involved in the adsorption process, determination of maximum capacity and apply mathematical models to understand the mechanism involved.

\section{A. Reagents}

\section{MATERIAL AND METHODS}

Chemicals used were of analytical grade. They included origin glacial acetic acid $\left(\mathrm{CH}_{3} \mathrm{COOH}\right)$ from Mallinckrodt, acetonitrile HPLC grade $\geq 99.9 \%\left(\mathrm{C}_{2} \mathrm{H}_{3} \mathrm{~N}\right)$ from Sigma-Aldrich (St. Louis, MO, USA), potassium bromide $(\mathrm{KBr})$ from Sigma-Aldrich, chloramphenicol $\left(\mathrm{C}_{11} \mathrm{H}_{12} \mathrm{Cl}_{2} \mathrm{~N}_{2} \mathrm{O}_{5}\right)$ from Proton Research, sodium hydroxide $(\mathrm{NaOH})$ and nitric acid $\left(\mathrm{HNO}_{3}\right)$ from Impex. 


\section{B. Collection and Preparation of Material}

The leaves of the cattail were collected in a weir located in the rural area of the countryside of São Paulo state, Brazil, with approximate coordinates $23^{\circ} 02^{\prime} 48.9^{\prime \prime} \mathrm{S} 49^{\circ} 53^{\prime} 12.6^{\prime \prime} \mathrm{W}$.

The biomass was prepared by washing the leaves of T. angustifolia L. with distilled water, in order to remove possible impurities from nature. Then, it was dried in an oven at $100^{\circ} \mathrm{C}$ for 24 hours before being crushed in a knife mill. In order to select a granulometry with a higher surface area, the biomass fractionated in sieves $(63 \mu \mathrm{m}$ to $106 \mu \mathrm{m})$ was selected for the study. In order to remove water-soluble organic molecules that may influence the adsorption of antimicrobials in the active sites of the biomass, the material was washed in a Sohxlet system using only ultrapure water $\left(18.2 \mathrm{M} \Omega . \mathrm{cm}\right.$ at $\left.25^{\circ} \mathrm{C}\right)$. The material obtained, after washing, was dried in an oven at $50^{\circ} \mathrm{C}$ and stored in a desiccator for later use (Fig. 2).

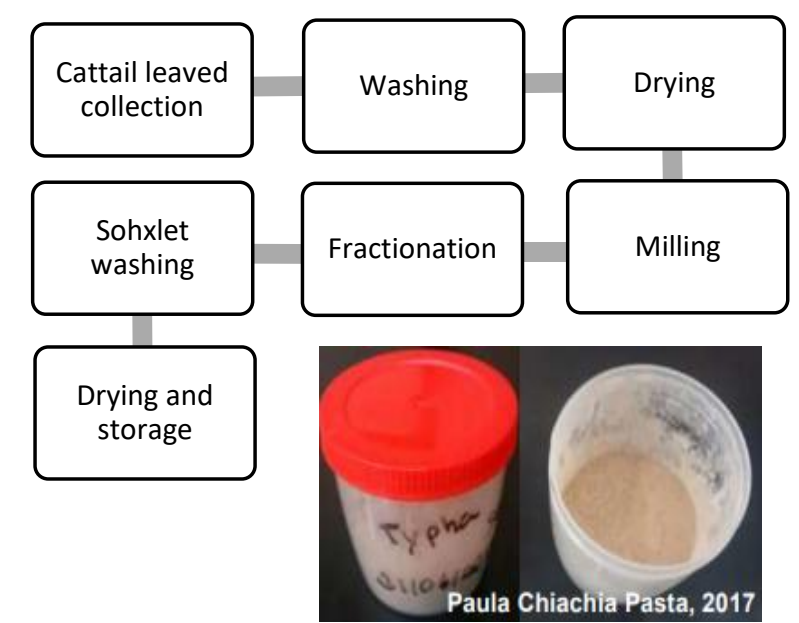

Fig. 2. Flowchart for preparing and obtaining the biosorbent. Source: Paula Chiachia Pasta, 2017.

\section{Characterization of the Adsorbent \\ 1) FTIR characterization}

Functional groups were identified using the Fourier transform infrared spectrometer (FTIR), Nicolet NEXUS 670, 4,000-400 $\mathrm{cm}^{-1}$ spectrum range with 200 scans and $4 \mathrm{~cm}^{-1}$ resolution. The equipment used for such analysis is found in the Department of Chemistry and Biochemistry of the Institute of Biosciences of Botucatu, UNESP, Botucatu campus. The samples were prepared in the form of $\mathrm{KBr}$ tablets containing $1 \%$ (m: $\mathrm{m})$ of the material.

\section{2) NMR characterization}

High resolution solid state nuclear magnetic resonance (NMR) spectroscopy on the Agilent DD2 spectrometer in a 5.9 Tesla magnetic field. The NMR spectra of the cattail were obtained from the solid sample, being packaged in $4 \mathrm{~mm}$ diameter zirconia rotors. The ${ }^{13} \mathrm{C}$ experiments were carried out in the magical angle rotation condition (MAS) with a frequency of $5 \mathrm{kHz}$, using the ${ }^{1} \mathrm{H} \rightarrow{ }^{13} \mathrm{C}$ cross polarization technique (CP). The Hartmann-Hahn contact time was $1 \mathrm{~ms}$ and the $\pi / 2$ pulse of ${ }^{1} \mathrm{H}$ lasted $6 \mu$ s. During the acquisition of the 13C signal, $1 \mathrm{H}$ heteronuclear decoupling with $100 \mathrm{kHz}$ nutation was applied. For each spectrum, around 20,000 signals were collected with a waiting time of $5 \mathrm{~s}$. The chemical shift of ${ }^{13} \mathrm{C}$ was referenced with respect to tetramethylsilane (TMS), using a solid sample of adamantane as a secondary standard, whose $\mathrm{CH}_{2}$ resonance is observed at $38.6 \mathrm{ppm} / \mathrm{TMS}$. Such experiments were carried out at the Nuclear Magnetic Resonance Laboratory of the São Carlos Institute of Physics of the University of São Paulo (IFSCUSP).

\section{3) Characterization by SEM}

The morphological analysis of the biosorbent was determined by Scanning Electron Microscopy (SEM), brand FEI and model Quanta 200, at the Center for Electronic Microscopy of the Biosciences Institute of Botucatu - UNESP / Botucatu campus.

\section{4) Characterization by $\mathrm{pH}_{P Z C}$}

The $\mathrm{pH}_{\mathrm{PZC}}$ of $\mathrm{T}$. angustifolia was determined through a batch experiment using $25 \mathrm{mg}$ of cattail, being transferred to a $50 \mathrm{~mL}$ Falcon tube containing $25 \mathrm{~mL}$ of aqueous solution, whose $\mathrm{pH}$ values were in the range between 2 to 12 . The initial $\mathrm{pH}$ was adjusted using dilute aqueous solutions of $\mathrm{HNO}_{3}$ and $\mathrm{NaOH}$. The tubes were subjected to agitation for 24 hours and the final $\mathrm{pH}$ was determined using the PHtek PHS-3B bench top digital $\mathrm{pH}$ meter. Such an experiment was carried out at the Department of Chemistry and Biochemistry at the Botucatu Biosciences Institute at UNESP Botucatu campus. 


\section{5) Characterization by BET}

The surface area was determined by the BET method, and the pore volume distribution was determined from the $77 \mathrm{~K}$ nitrogen adsorption and desorption isotherms, using the Barrett-Joyner-Halenda (BJH) method, using the Micromeritics ASAP 2010 equipment. The equipment used for such analysis is found in the Department of Chemistry and Biochemistry of the Institute of Biosciences of Botucatu, UNESP, Botucatu campus.

\section{Preparation of Solutions}

The solutions used in all experiments were prepared with reagents of analytical grade, HPLC grade and ultrapure water (Milli-Q system - resistivity $18.2 \mathrm{M} \Omega . \mathrm{cm}$ at $25^{\circ} \mathrm{C}$ ), being kept in containers protected from light and refrigerated. For standardization of the method, solutions with the drug, comprising the range between $0.1 \mathrm{mg} \cdot \mathrm{L}^{-1}$ and $10 \mathrm{mg} \cdot \mathrm{L}^{-1}$ (APPENDIX 1A, 1B, 1C and 1D), were obtained for the construction of the analytical calibration curve (Fig. 3) at $278 \mathrm{~nm}$ on the UPLC.

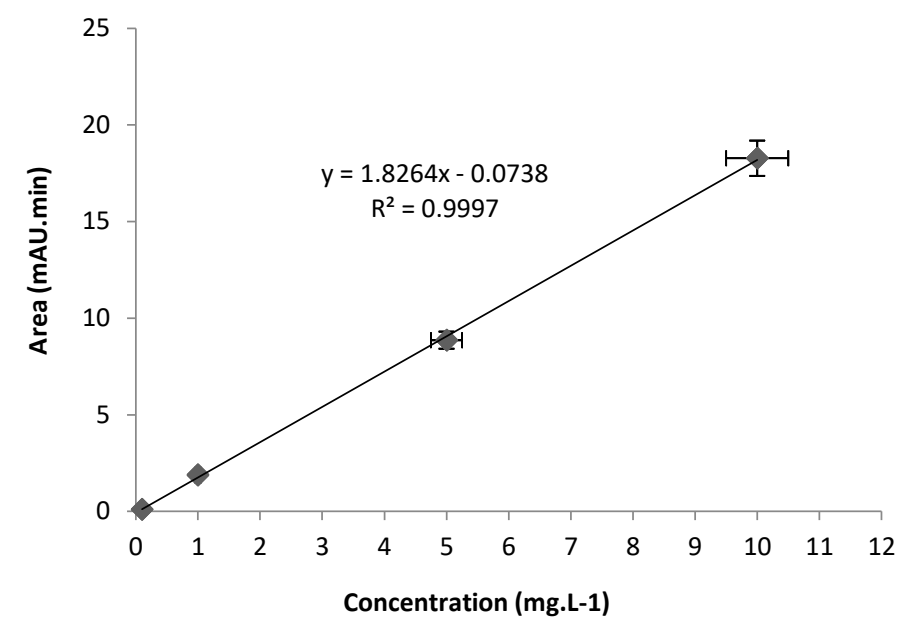

Fig. 3. Calibration curve for chloramphenicol.

The working solutions used to optimize the system were prepared from dilutions of the stock solution of $100 \mathrm{mg} \cdot \mathrm{L}^{-1}$ of the studied antibiotic, dissolved in $2 \%$ of glacial acetic acid. The solutions can be stored in a period of 6 months at $-18{ }^{\circ} \mathrm{C}$, while the stability of the compound is reduced to 3 months at $4{ }^{\circ} \mathrm{C}$ [76].

\section{E. Batch Tests for Removal / Adsorption of Antimicrobial}

The proposed experiments were carried out in batches by mixing the volume $(20 \mathrm{~mL})$ of the antimicrobial solution with $100 \mathrm{mg}$ of biomass of cattail at a temperature close to $25^{\circ} \mathrm{C}$. After stirring and decanting the particles, the filtration of the mixture contained was carried out in tubes with polyvinylidene fluoride (PVDF) syringe filters, measuring $17 \mathrm{~mm}$ and $0.45 \mu \mathrm{m}$ (porosity), for storage of the supernatant in vials with a volume of $2 \mathrm{~mL}$. Then, the supernatant was quantified by UPLC, and the experiments were analyzed in triplicate. In order to quantify the results, the data were calculated and analyzed according to the following equations ( 1 and 2), also considering their respective standard errors included in the graph.

$$
R=\frac{\left(C_{0}-C_{e}\right)}{C_{0}} \times 100
$$

where, $R$ represents removal of the analyte, $C_{0}$ the initial concentration $\left(\mathrm{mg} \cdot \mathrm{L}^{-1}\right)$ of the sample and $\mathrm{C}_{\mathrm{e}}$ the equilibrium concentration after adsorption $\left(\mathrm{mg} \cdot \mathrm{L}^{-1}\right)$.

$$
q_{e}=\frac{\left(C_{0}-C_{e}\right) \times V}{m}
$$

where, $\mathrm{q}_{\mathrm{e}}$ consists of the amount of the analyte adsorbed per gram of biosorbent $\left(\mu \mathrm{g} \cdot \mathrm{g}^{-1}\right)$, after unit conversion; $\mathrm{C}_{0}$ is the initial concentration $\left(\mathrm{mg} \cdot \mathrm{L}^{-1}\right)$ of the sample and $\mathrm{C}_{\mathrm{e}}$ is the equilibrium concentration after adsorption $\left(\mathrm{mg} \cdot \mathrm{L}^{-1}\right)$; $\mathrm{V}$ is the volume of the working solution $(\mathrm{L})$ and $\mathrm{m}$ is the mass of the biosorbent used (g).

\section{F. Preliminary Tests}

In order to adjust the most suitable parameters for the method, preliminary tests containing the white group, control and sample were carried out. The white group is characterized as the experiment consisting of only ultrapure water and cattail; the control group was prepared with ultrapure water and 
chloramphenicol and, finally, the sample was composed of ultrapure water, chloramphenicol and cattail. Such groups were established under the following conditions: the $50 \mathrm{ml}$ Falcon tubes of the white group had only biomass $(100 \mathrm{mg})$ in a solution of $20 \mathrm{ml}$ of ultrapure water, while the control group contained 20 $\mathrm{ml}$ solution of the antimicrobial $\left(1 \mathrm{mg} \cdot \mathrm{L}^{-1}\right)$, and the sample group $100 \mathrm{mg}$ of cattail in a $20 \mathrm{~mL}$ solution of the antimicrobial $\left(1 \mathrm{mg} \cdot \mathrm{L}^{-1}\right)$. All tubes were shaken for 24 hours, and the $\mathrm{pH}$ of the solution was previously established close to 6.0 .

\section{G. Influence of $p H$}

In the study of the influence of $\mathrm{pH}$ on the adsorption process, the Falcon tubes, containing the biomass $(100 \mathrm{mg})$ and the $20 \mathrm{~mL}$ solution of the antimicrobial $\left(1 \mathrm{mg} \cdot \mathrm{L}^{-1}\right)$, were stirred for 24 hours, and the $\mathrm{pH}$ of the solution was previously established close to 6.0. This $\mathrm{pH}$ value was maintained due to the pKa values of the analyte, as well as the $\mathrm{pH}_{\mathrm{PZC}}$ value of the biosorbent, and the $\mathrm{pH}$ value 6.0 represents the ideal condition for adsorption to occur, which will be discussed in more detail in Results and Discussion.

\section{H. Adsorption Kinetics}

In the kinetic study, Falcon tubes, containing the biomass, were shaken with the antimicrobial solution at a fixed concentration $\left(1 \mathrm{mg} \cdot \mathrm{L}^{-1}\right)$ and $\mathrm{pH}$ adjusted to the ideal range according to the results obtained in the previous experiment. Then, the dynamic contact time was studied in an interval of 1 hour to 48 hours. With kinetic data, mathematical models of pseudo-first [77] and second order [78] were applied to understand the mechanism involved in the adsorption process.

\section{Kinetic Models}

The kinetic study demonstrates the speed of removal of materials in solution, with simple kinetic models being generally used as first and second order equations to represent adsorption systems [79]. Thus, the pseudo-first (equation (3)) and pseudo-second order (equation (4)) models were used, in order to verify the best correlation of experimental data.

Pseudo-first order [77]:

$$
\log \left(q_{e}-q_{t}\right)=\log q_{e}-\frac{K_{1} t}{2,303}
$$

Pseudo-second order [78]:

$$
\frac{t}{q_{t}}=\frac{1}{K_{2} \times q_{e}{ }^{2}}+\frac{t}{q_{e}}
$$

where, $\mathrm{q}_{\mathrm{e}}$ and qt are the amounts adsorbed per gram of adsorbent at equilibrium and at time $\mathrm{t} ; \mathrm{K}_{1}$ and $\mathrm{K}_{2}$ are the pseudo-first and second order adsorption rate constants.

The adsorption kinetics is of fundamental importance for the design of batch effluent treatment systems, since it is possible to determine the equilibrium time and the speed at which the adsorption occurs [80]. The temporal variation of the adsorption capacity, that is, the time necessary to reach equilibrium, can be subjected to different mathematical treatments, which are considered kinetic models of adsorption. The method used to generate the experimental data is fairly simple, adding a known amount of solute to a system containing a known amount of adsorbent, under constant agitation and temperature, varying only the time. The difference between the amount added and the amount remaining in the solution, gives the value of the amount adsorbed on the surface of the adsorbent [81].

Adsorption does not involve just a single mechanism. This process consists of several mechanisms that differ quantitatively and qualitatively according to the species involved. The mechanism of antibiotic adsorption on porous adsorbents may involve the following steps:

1. Diffusion of antibiotic molecules in solution to the outer surface of the solid (adsorbent);

2. Adsorption at the external surface sites;

3. Internal diffusion of the antibiotic within the particle, either by diffusion in the pores, surface diffusion, or both.

Thus, the kinetic models of adsorption can be divided into two types, models based on diffusion models and those based on reaction. Pseudo-first order and pseudo-second order models are the two most commonly used reaction-based kinetic models [82]. The pseudo-first order and pseudo-second order are equations used when adsorption occurs by chemisorption [78].

\section{J. Maximum Adsorption Capacity}

Tests with different concentrations of the analyte $\left(0.1\right.$ to $\left.10 \mathrm{mg} \cdot \mathrm{L}^{-1}\right)$ were performed, fixing the ideal $\mathrm{pH}$ as well as the contact time determined in the previous section. The data obtained were applied to some mathematical models, such as Langmuir and Freundlich, to determine the maximum capacity and the 
constants involved in the adsorption process. The results were compared with existing data in the literature for the analyte studied.

\section{K. Mathematical Models}

The Langmuir model describes monolayer adsorption, which is considered that the adsorbed molecules do not interact with each other and the adsorbates adsorb at defined sites. To calculate the adsorption capacity at equilibrium using the Langmuir model, the linearized Hannes-Woolf equation (Equation 5) [83] is used.

$$
\frac{C_{e}}{q_{e}}=\frac{1}{q_{m a ́ x} \times K_{L}}+\frac{C_{e}}{q_{m a ́ x}}
$$

where, $\mathrm{q}_{\mathrm{e}}$ is the amount of solute adsorbed per gram of adsorbent at equilibrium, $\mathrm{q}_{\text {máx }}$ is the maximum adsorption capacity, $\mathrm{K}_{\mathrm{L}}$ is the adsorvate / adsorbent interaction constant and $\mathrm{C}_{\mathrm{e}}$ is the concentration of the adsorbate at equilibrium.

Another model used to describe the experimental data is the Freundlich model, which describes the multilayer adsorption considering the heterogeneous adsorbent surface. The Freundlich model is described by the linearized equation according to Equation 6 [84].

$$
\log q_{e}=\log K_{F}+\frac{1}{n} \log C_{e}
$$

where, $\mathrm{q}_{\mathrm{e}}$ is the amount of adsorbed solute, $\mathrm{C}_{\mathrm{e}}$ is the equilibrium concentration in solution, $1 / \mathrm{n}$ is the constant related to the heterogeneity of the surface and $\mathrm{K}_{\mathrm{F}}$ is the Freundlich adsorption capacity constant.

\section{Preparation of Activated Carbon of T. angustifolia $L$.}

In order to increase the removal of the antibiotic from the aqueous medium, activated carbon was produced from the powder prepared previously from the cattail leaves. Thus, the adapted method of reference [85] served as a model for obtaining coal, using an INTI muffle $n^{\circ}$ TL-1200/401/09 with a gas nitrogen flow controller (MKS Instruments Type 247) at the rate of $80 \mathrm{~mL} \mathrm{min-1,} \mathrm{according} \mathrm{to} \mathrm{the} \mathrm{ramp} \mathrm{in}$ Fig. 4.

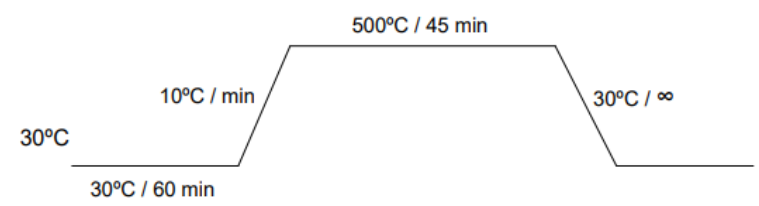

Fig. 4. Activated carbon of T. angustifolia L prepared using muffle with heating ramp.

\section{UPLC Analysis}

The quantification of the analyte (chloramphenicol) was done in the supernatant, after filtering the mixture, from the batch experiments using the UPLC system Thermo / Dionex Ultimate 3000 (Thermo Scientific, Germany). Equipment available at the Department originating from FAPESP Project (2011/16291-9).

According to the previous methodology of the reference [86], with chromatographic separation in reverse phase and ACE® $5 \mathrm{C} 18$ column $(250 \mathrm{~mm} \times 4.6 \mathrm{~mm}, 5 \mu \mathrm{m})$ protected by an ACE® $5 \mathrm{C} 18$ column $(10 \mathrm{~mm}$ $\times 4.6 \mathrm{~mm}, 5 \mu \mathrm{m})$, was for this project, a chromatographic separation in reverse phase with the Luna $2.5 \mu$ C18 column (2) - HST $(50 \mathrm{~mm} \times 2.00 \mathrm{~mm}, 2.5 \mu \mathrm{m})$ protected by a Phenomenex Ultra Holder C18 column $(2.1 \mathrm{~mm} \times 4.6 \mathrm{~mm})$. The column temperatures and their injection were maintained at $25^{\circ} \mathrm{C}$. The sample was injected through a fixed sample circuit with a volume of $20 \mu \mathrm{L}$. The UV detector was used, and the best wavelength was adjusted according to the standards for the antibiotic, with wavelengths 250, 270, 278 and $280 \mathrm{~nm}$ being chosen, with better resolution at $278 \mathrm{~nm}$. The system was operated as a gradient flow at a rate of $0.4 \mathrm{~mL} \cdot \mathrm{min}^{-1}$, using acetonitrile and ultrapure water with $0.1 \%$ acid $30{ }^{\circ} \mathrm{C} / 60 \mathrm{~min} 10^{\circ} \mathrm{C} / \mathrm{min}$ $500{ }^{\circ} \mathrm{C} / 45 \mathrm{~min} 30^{\circ} \mathrm{C} /$ as the mobile phase. $\infty 57$ acetic, the proportion being 10:90 (v/v), respectively, up to 1.4 minutes, changing to $23: 77(\mathrm{v} / \mathrm{v})$ between 1.4 and 4 minutes, returning to 10:90 (v/v) after 4.1 minutes until the end of the race. In addition, the equipment used in the analyzes has an injection variation coefficient $(\mathrm{CVI})<2.5 \%$ and variation coefficient between analyzes (CVA) $<3.0 \%$, detection limit (LD) estimated by visual method close to the $0.0532 \mathrm{mg} \mathrm{L}-1$, while the limit of quantification (LQ) around 0.0617 $\mathrm{mg} \cdot \mathrm{L}^{-1}$, by method based on parameters of the analytical curve. 


\section{RESUlTS AND DisCUSSION}

\section{A. Characterization of the Biosorbent T. angustifolia L.}

\section{1) FTIR characterization}

The choice of the most promising material for the proposed purpose was made through a screening, which consisted of FTIR analysis of different parts of the plant. Due to the great similarity of the spectra obtained for the different parts investigated (leaves, rhizome, and roots), it was decided to work with the leaves due to the higher yield in relation to biomass production. Fig. 5 shows the FTIR spectra of T. angustifolia with important wavenumbers highlighted.

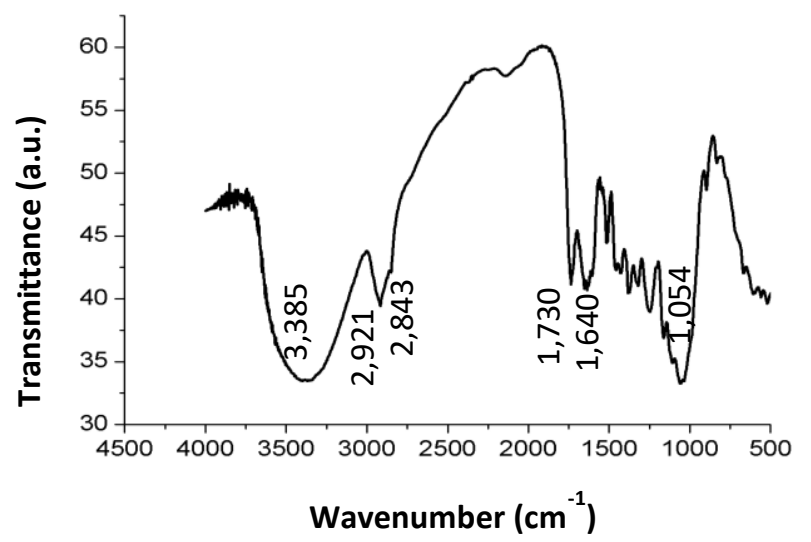

Fig. 5. FTIR spectrum from leaves of the T. angustifolia L. Source: Authorship.

From the spectra shown in Fig. 5, it is possible to identify that the material has main bands characteristic of a polysaccharide. This result is already expected because it is a natural material in which its main constituent is cellulose (glycosidic groups). The intense band observed at $3,385 \mathrm{~cm}^{-1}$ is attributed to the vibrational stretching of hydroxyl groups $\mathrm{OH}$ existing in each glycosidic unit of the cellulose polymer [87]. In the region of 2,921 and $2,843 \mathrm{~cm}^{-1}$, two bands are observed that can be attributed to the symmetrical and asymmetric vibrational stretching of $\mathrm{CH}_{2}$, respectively [87],[88]. The band located in the 1,730 region is attributed to the $\mathrm{C}-\mathrm{H}$ and $\mathrm{C}-\mathrm{O}$ bonds of the acetyl group in hemicellulose, while the $1,640 \mathrm{~cm}^{-1} \mathrm{band}$ is attributed to the $\mathrm{C}=\mathrm{O}$ stretch present in primary amides. The $1,054 \mathrm{~cm}^{-1}$ band is attributed to the $\mathrm{C}-\mathrm{O}$ stretching of alcohols in cellulose and lignin and to the C-O-C stretching in hemicellulose and cellulose. The less intense signs observed in the regions of 1,$607 ; 1,511 ; 1,427$ and $1,323 \mathrm{~cm}^{-1}$ are present in lignin and are characteristic of aromatic ring vibrations [55]. The presence of the aforementioned groups is essential in directing the isolated electrons to promote the adsorption of the analytes with the biosorbent, being also dependent on the $\mathrm{pH}$ of the medium.

\section{2) NMR characterization}

As for the cross-polarized NMR spectrum, there is a strong dipolar coupling for the C-O and O-C-O carbons, and moderate for the other groups, as shown in Fig. 6.

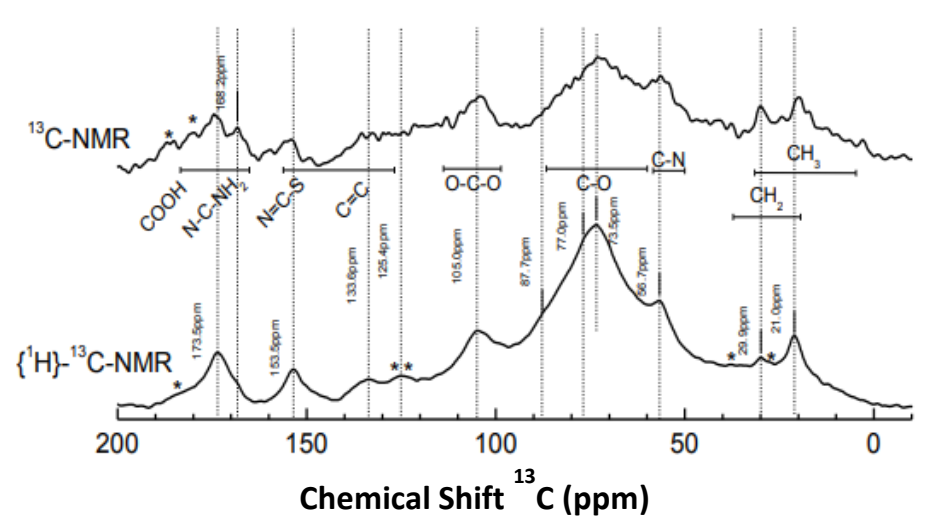

Fig. 6. NMR spectrum of cross polarization $\{1 \mathrm{H}\}-13 \mathrm{C}$ (lower trace) and direct polarization (upper trace) of the cattail leaf. Source: Authorship.

In the region of 50-80 ppm (Fig. 6), it is possible to see a small peak consistent with the C-N bond (56 ppm) and another well resolved at $73.2 \mathrm{ppm}$, associated with the $\mathrm{C}-\mathrm{O}$ bond (Fig. 6). In addition to the other 
peaks identified as: $\mathrm{CH} 2$ (29 ppm), CO (73-77 ppm), OCO (105 ppm), COOH (173 ppm) [89] with strong dipole coupling for $\mathrm{CO}$ type carbons and OCO, and moderate to $\mathrm{N}=\mathrm{CS}$ (153 ppm), NC-NH2 (168 ppm) and $-\mathrm{CN}(56 \mathrm{ppm})$. The presence of peaks with nitrogen groups, although moderate, also favors interaction with the analyte.

\section{3) Characterization by SEM}

To evaluate the morphology of T. angustifolia L., considering particle structure, texture and roughness of the material, SEM was used, and thus, micrographs of different magnifications were obtained (Fig. 7).
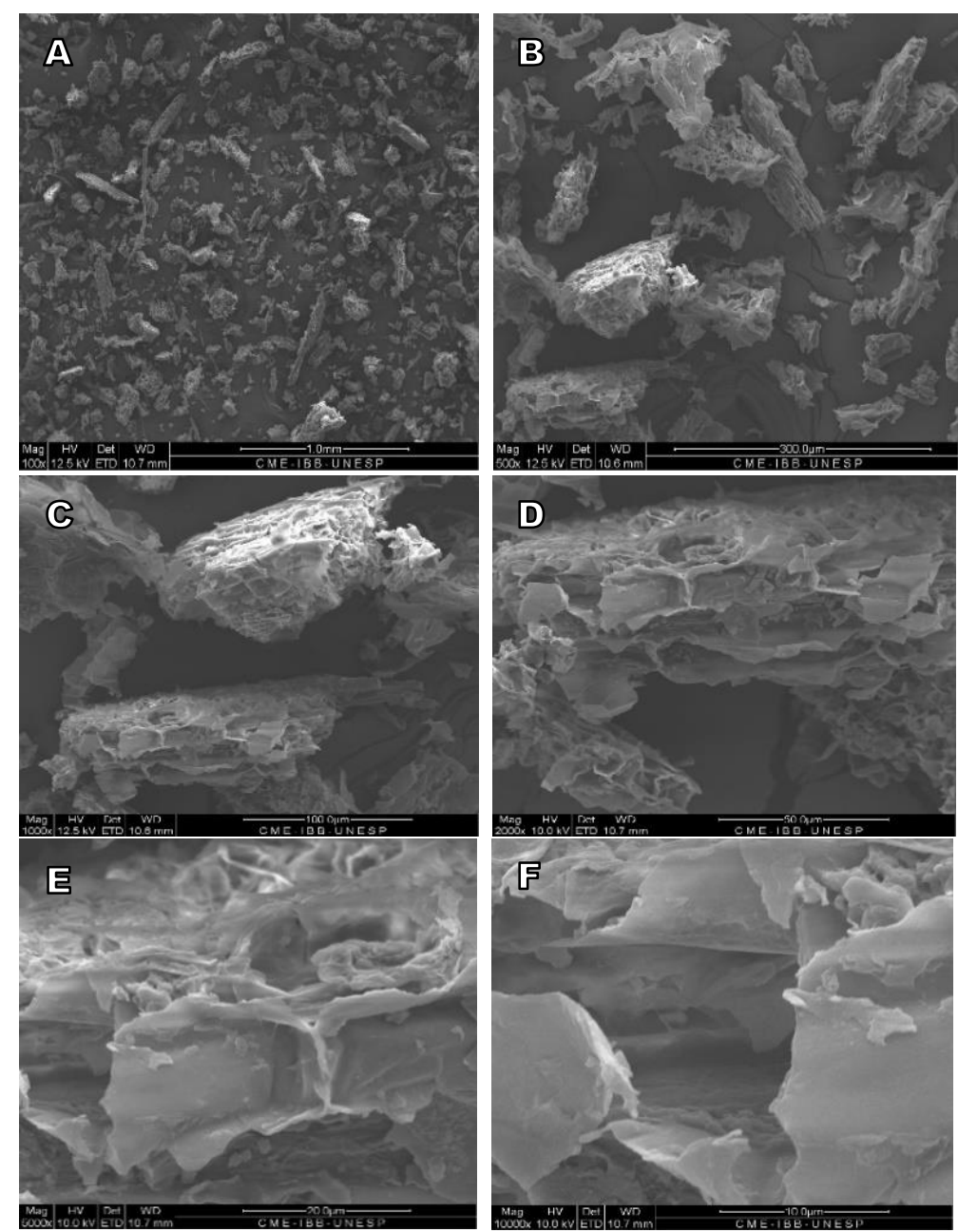

Figure 7 - Images obtained by SEM of in natura cattail leaf powder. Micrograph A has a magnification of 100 times, B of 500 times, C of 1,000 times, D of 2,000 times, E of 5,000 times and F of 10,000 times. Source: Authorship.

The images of the particles (leaf segments) indicate a material with a heterogeneous surface composed of parallel plates where a large number of channels are distributed, which are characteristic of such fibrous plants [90],[91].

4) Characterization by $\mathrm{pH}_{P Z C}$

Highlighting yet another determinant characterization, it is possible to verify the zero-charge point ( $\mathrm{pH}_{\mathrm{PZC}}$ ), responsible for assessing whether the material surface is positively or negatively charged depending on the $\mathrm{pH}$ of the medium. The $\mathrm{pH}_{\mathrm{PZC}}$ signals the $\mathrm{pH}$ at which the material surface is at equivalent loads. Below the $\mathrm{pH}_{\mathrm{PZC}}$ value the material surface is positively charged, favoring the adsorption of the deprotonated analyte. Above the $\mathrm{pH}_{\mathrm{PZC}}$ value, the material surface has a negative charge, being effective in adsorption of the protonated analyte.

Therefore, it is also necessary to consider the pKa value of chloramphenicol equal to 5.5, as it is decisive in relation to the ionic form in which the substance will be depending on the $\mathrm{pH}$ of the medium. Thus, it can be emphasized that below the $\mathrm{pH}_{\mathrm{PZC}}$ value $=5.75$ (Fig. 8), the surface of the cattail particle shows positive charges, favoring the adsorption of the deprotonated parts of the analyte, whereas, around the value of $\mathrm{pH}_{\mathrm{PZC}}$, there is a greater interaction between the charges of both the particle (balanced charges) and the analyte that is negatively charged. It is concluded that the ideal $\mathrm{pH}$ range must be established between 5.5 and 6.0 in order to optimize the chemisorption. 


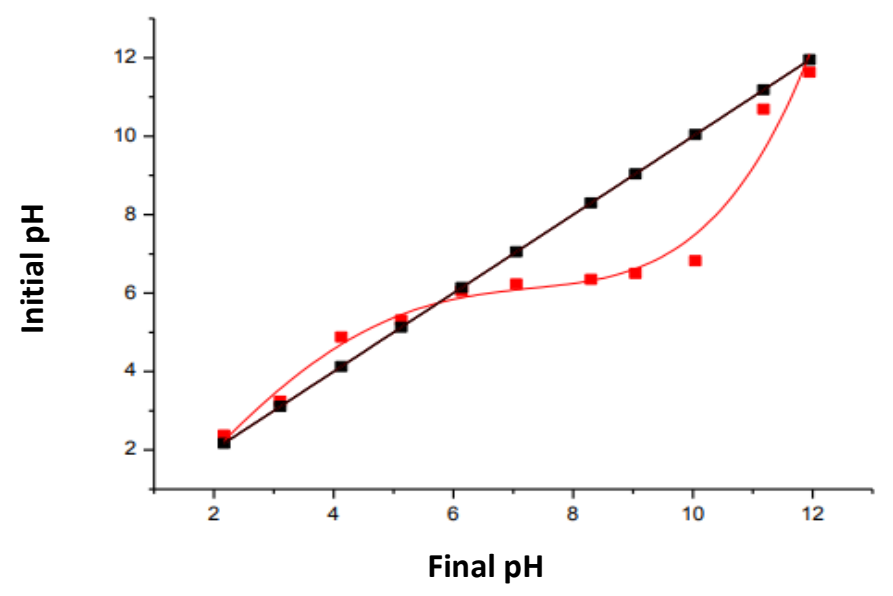

Fig. 8. Zero Charge Point ( $\left.\mathrm{pH}_{\mathrm{PZC}}\right)$ of the cattail leaf. Source: Authorship.

\section{5) Characterization by BET}

To quantify the pore volume and surface area of the biosorbent, the nitrogen adsorption isotherm at 77 $\mathrm{K}$ was used, which, for that material, is shown in Fig. 9.

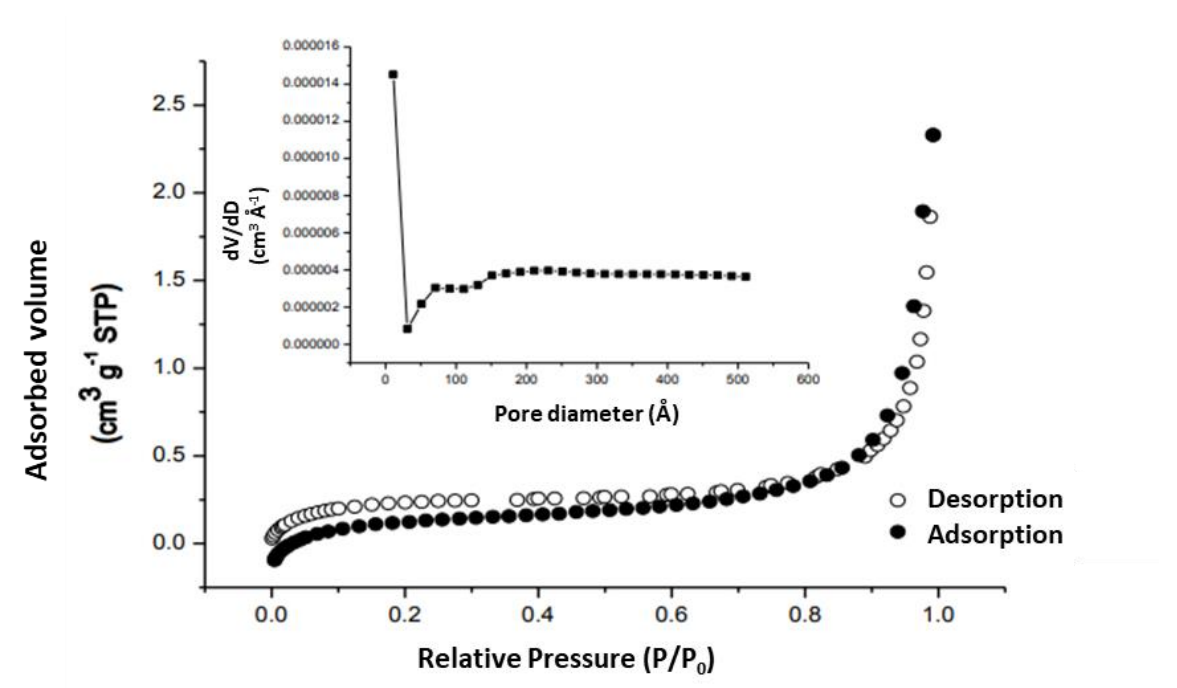

Fig. 9. Nitrogen adsorption / desorption isotherms and pore size distribution for the biosorbent consisting of cattail leaves. Source: Authorship.

It is possible to verify that the profile of the isotherms obtained for the adsorbent prepared from cattail leaves (Fig. 9) is similar to the type II isotherm, according to the IUPAC adsorption isotherm classification. Also according to IUPAC, this type of isotherm proves to be characteristic of materials with a low surface area (less than $1 \mathrm{~m}^{2} \mathrm{~g}^{-1}$ ), non-porous or with macroporosity, in addition to mono and multilayer adsorption; besides it is often used to indicate the stage in which the monolayer coverage is complete and, in multilayer, is about to begin [92].

\section{B. Characterization of the Activated Carbon of the Biosorbent T. angustifolia L. \\ 1) FTIR characterization}

The activated carbon generated after muffle pyrolysis of the powder of T. angustifolia L. leaves (Fig. 10) was characterized by analyzing the infrared region, making it possible to verify bands that remained in relation to the biosorbent in natura and other differentiated regions.

Analyzing the FTIR spectrum presented in Fig. 11, it is possible to compare it with others present in the literature that are similar to each other because they are spectra referring to activated carbon from fresh cattail leaves [93], [94]. The intense band observed at $1,600 \mathrm{~cm}^{-1}$ is possibly attributed to the stretching of groups $\mathrm{C}=\mathrm{O}$ existing in carboxyls, ketones, aldehydes and lactones [90]. Vibrational stretches of aromatic ring or $\mathrm{C}=\mathrm{C}$ type bonds are observed around $1,433 \mathrm{~cm}^{-1}$, and the presence of these functional groups indicates the formation of a group containing carbonyl and aromatization of the precursor [95]. While the band around $1,314 \mathrm{~cm}^{-1}$, it is typically represented by the C-O group [90]. 


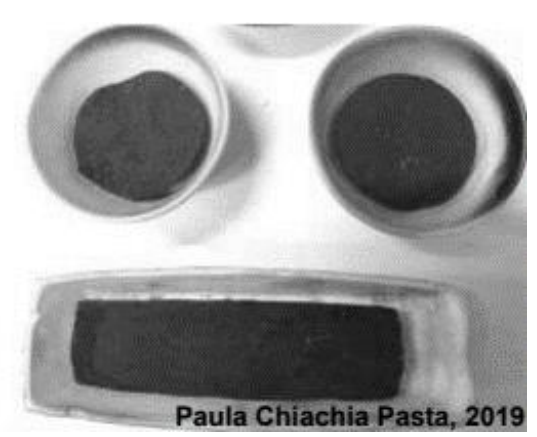

Fig. 10. Activated carbon produced after burning of the biosorbent (cattail) in muffle. Source: Authorship.

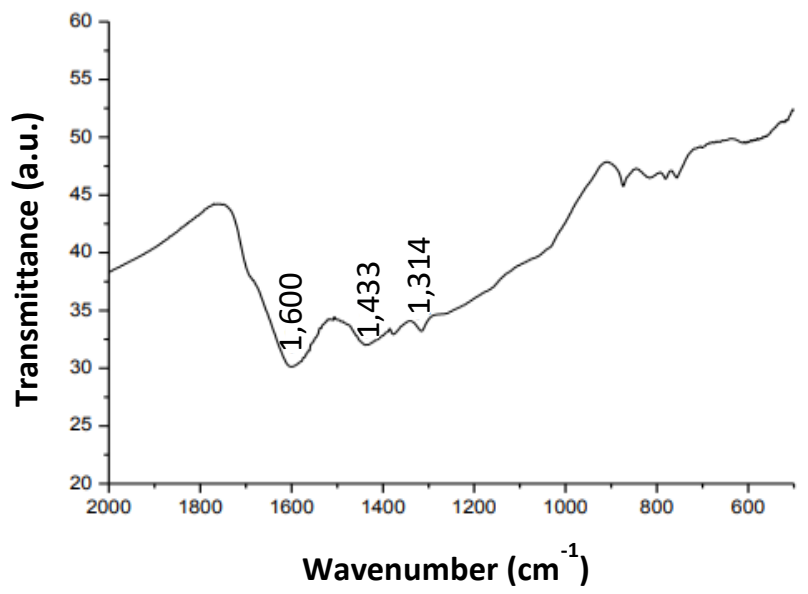

Fig. 11. Infrared spectrum from the activated carbon of the biosorbent (cattail). Source: Authorship.

2) Characterization by $\mathrm{pH} H_{P Z C}$

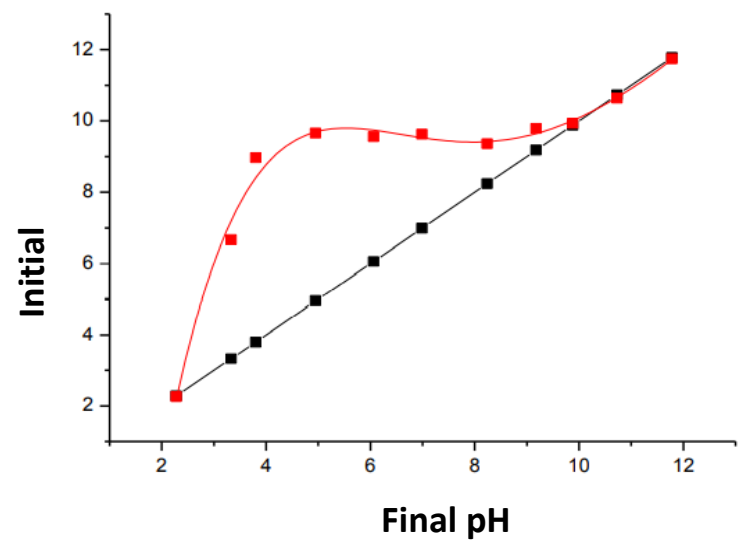

Fig. 12. Zero Charge Point ( $\mathrm{pH}_{\mathrm{PZC}}$ ) of activated carbon produced from the powder of cattail leaves. Source: Authorship.

Experiments of $\mathrm{pH}_{\mathrm{PZC}}$ were carried out in order to characterize in more detail the behavior of the particles of activated carbon particles as a function of the $\mathrm{pH}$ change of the medium. According to studies of reference [85], the vast majority of activated carbon samples showed alkaline $\mathrm{pH}(\mathrm{pH}>7.0)$.

A $\mathrm{pH}_{\mathrm{PZC}}$ value close to 10.30 was obtained when applying the fifth-degree polynomial function in the Origin software (Fig.12).

\section{Chloramphenicol Analyte Adsorption Studies \\ 1) Influence of $\mathrm{pH}$}

As previously presented, all solutions of the experiments were previously adjusted to approximately $\mathrm{pH}$ 6.0 due to the values of $\mathrm{pKa}$ and $\mathrm{pH}_{\mathrm{PZC}}$, since, at such $\mathrm{pH}$, the ionic form of the analyte presents negative charge, while the surface of the biosorbent particle is close to the balance of charges, conditions that can favor the establishment of interactions / connections between the surface of the adsorbent and the adsorbate.

It is possible that the electrostatic interactions between charges of the adsorbent and adsorbate have altered the charge distribution in the aromatic ring due to the resonance effects of the substituents, since the nitro group (substituent and $\pi$-electron acceptor) in the chloramphenicol and, the deprotonated hydroxyls, may have interacted with protonated groups of the biosorbent particle [96]. 
Tests were performed with cattail activated carbon and varying the $\mathrm{pH}$ of the solution between 4.0 and 8.0, which resulted in values of removal percentage with low variation between them with an average of $55.37 \pm 1.99 \%$ (RSD), except at $\mathrm{pH}$ close to 8.0 , with removal around $44.08 \pm 1.05 \%$ (RSD), being lower compared to the others. Such results infer that the influence of the $\mathrm{pH}$ of the solution is not a determining factor for the removal of the analyte. Therefore, the $\mathrm{pH}$ fixed around 6.0 was established for the following tests, not only for the ideal condition of adsorption, but also to simulate more reproducible conditions in which such contaminated water can be found in nature, therefore it is not necessary to adjust the $\mathrm{pH}$ to extreme values.

2) Preliminary tests

In the initial stage of the experiments involving cattail and chloramphenicol, the following groups were prepared: white, control and sample, under the conditions. It was possible to verify that the peaks in the chromatogram of the white group, containing only cattails, did not coincide with the peak of the drug in the sample (cattails with chloramphenicol), that is, the chloramphenicol retention time was specific and well defined, not hindering the integration the peak area for later calculation of the concentration after adsorption (APPENDIX 2A, 2B, 2C and 2D). In addition, there was no significant variation in the $\mathrm{pH}$ value after interaction, indicating that the adsorption was maintained under the conditions predicted between the pka of the drug and the $\mathrm{pH}_{\mathrm{PZC}}$ of the biosorbent. The results of the preliminary tests can be seen in Table III, being subjected to 24 hours of agitation.

TABLE III: PRELIMINARY RESULTS OF CHLORAMPHENICOL ADSORPTION BY THE BIOSORBENT T. ANGUSTIFOLIA L.

\begin{tabular}{cccc}
\hline Cattail $(\mathrm{mg})$ & Removal $(\%)$ & $\mathrm{q}_{\mathrm{e}}\left(\mu \cdot \mathrm{g}^{-1}\right)$ & Relative Standard deviation (R.S.D) \\
\hline 100.2 & 5.6160 & 11.0331 & 0.4438 \\
\hline
\end{tabular}

Other studies, involving chloramphenicol biosorption, showed removal rates close to or above $80 \%$ [51][54]. Comparing these data with the percentage of removal by fresh cattail leaves, it is noted that the techniques applied in the studies mentioned above (Photo-Fenton process, composites, activated carbon, magnetism), confer properties that favor the adsorption of more analytes complexes (high molecular mass, $\mathrm{pKa})$.

\section{3) Adsorption kinetics}

Regarding the minimum contact time for the drug to interact with the biosorbent surface, it was found that the equilibrium state can be reached after 4 hours of stirring between the solution containing the analyte and the biosorbent (Fig. 13) and the greatest removal in 24 hours.

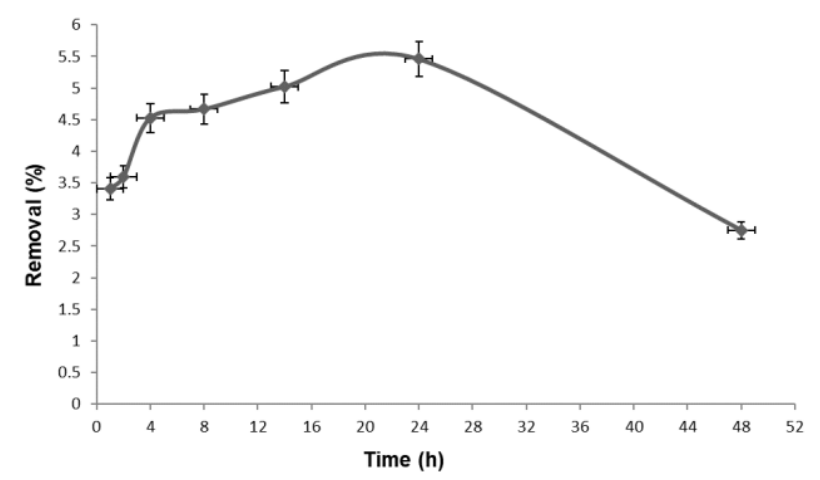

Fig. 13. Kinetic study of the removal of chloramphenicol by cattail in aqueous medium.

The model that best elucidates the adsorption kinetics for the drug under study is the pseudo-second order model (Fig. 15), with a correlation coefficient equal to 1 [78], as opposed to the graph in Fig. 14. The pseudo-second order model was also found in the reference [42] who used clay and zeolites modified by ionic liquid to increase the adsorption of chloramphenicol from aqueous medium.

The constants of qe and $\mathrm{K}$, as well as the correlation values were presented in Table IV.

TABLE IV: PARAMETERS OBTAINED FROM THE KinETIC MODELS OF PSEUdO-FIRST AND SECOND ORDER FOR THE DRUG CHLORAMPHENICOL

\begin{tabular}{ccccccc}
\hline & \multicolumn{3}{c}{ Pseudo-first order } & \multicolumn{3}{c}{ Pseudo-second order } \\
\hline $\begin{array}{c}\mathrm{q}_{\mathrm{e}}(\mathrm{exp})^{*} \\
\left(\mathrm{mg} \cdot \mathrm{g}^{-1}\right)\end{array}$ & $\begin{array}{c}\mathrm{q}_{\mathrm{e}}(\mathrm{cal})^{* *} \\
\left(\mathrm{mg} \cdot \mathrm{g}^{-1}\right)\end{array}$ & $\begin{array}{c}\mathrm{K}_{1} \\
\left(\mathrm{~h}^{-1}\right)\end{array}$ & $\mathrm{R}^{2}$ & $\begin{array}{c}\mathrm{q}_{\mathrm{e}}(\mathrm{cal})^{* *} \\
\left(\mathrm{mg} \cdot \mathrm{g}^{-1}\right)\end{array}$ & $\begin{array}{c}\mathrm{K}_{2} \\
\left(\mathrm{~g} \cdot \mathrm{mg}^{-1} \cdot \mathrm{h}^{-1}\right)\end{array}$ & $\mathrm{R}^{2}$ \\
0.0111 & 0.0041 & -0.1142 & 0.8956 & 0.0111 & $-3.5964 \times 10^{16}$ & 1 \\
\hline
\end{tabular}

* experimental; ** calculated. 
European Journal of Advanced Chemistry Research www.ej-chem.org

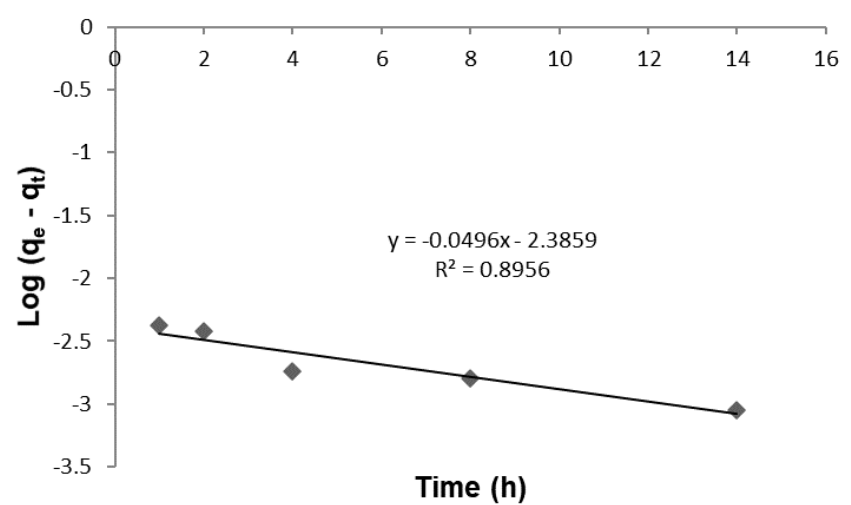

Fig. 14. Linearization of the adsorption kinetics graph, applying to the pseudo-first order model.

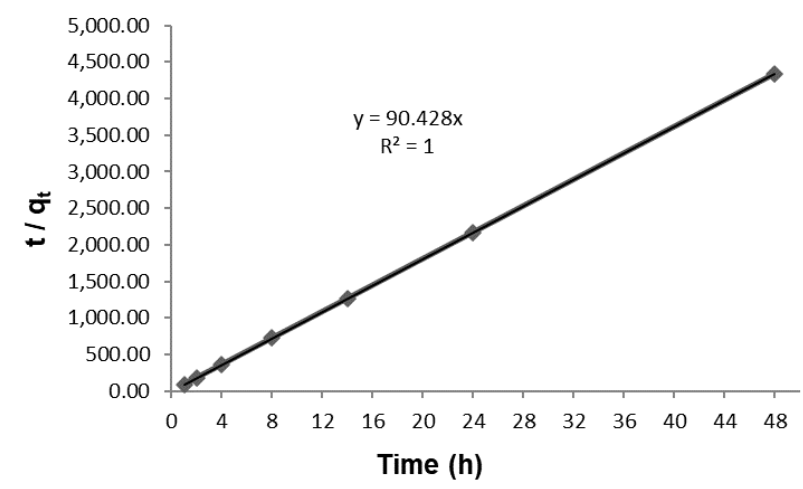

Fig. 15. Linearization of the adsorption kinetics graph, applying to the pseudo-second order model.

Observing the values of the calculated parameters, it is noted that both $K_{1}$ and $K_{2}$ present negative values, indicating low growth of the curve, not being favorable to a fast kinetics. The value obtained for the calculated $\mathrm{q}_{\mathrm{e}}$ is consistent with that observed by the isotherm of the pseudo-second order model, whose experimental $\mathrm{q}_{\mathrm{e}}$ value is observed in the isotherm. In addition, this model shows a multilayer adsorption and heterogeneous adsorbent surface.

\section{4) Maximum adsorption capacity}

As for the maximum adsorption capacity, maximum removal was obtained close to $5 \%$ from $1 \mathrm{mg}$. $\mathrm{L}^{-1}$ of the drug (APPENDIX 3). This value was investigated by varying the concentrations of chloramphenicol according to the adsorption isotherm in Fig. 16.

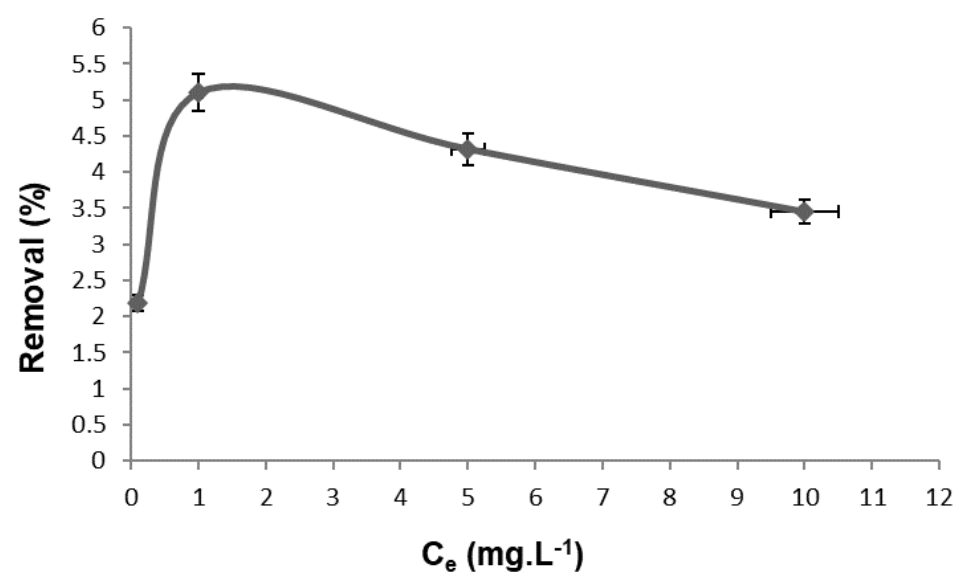

Fig. 16. Study of the maximum adsorption capacity of chloramphenicol by cattail in aqueous medium.

The isotherm data were applied to the Langmuir and Freundlich models through linearization (Fig. 17 and 18). 


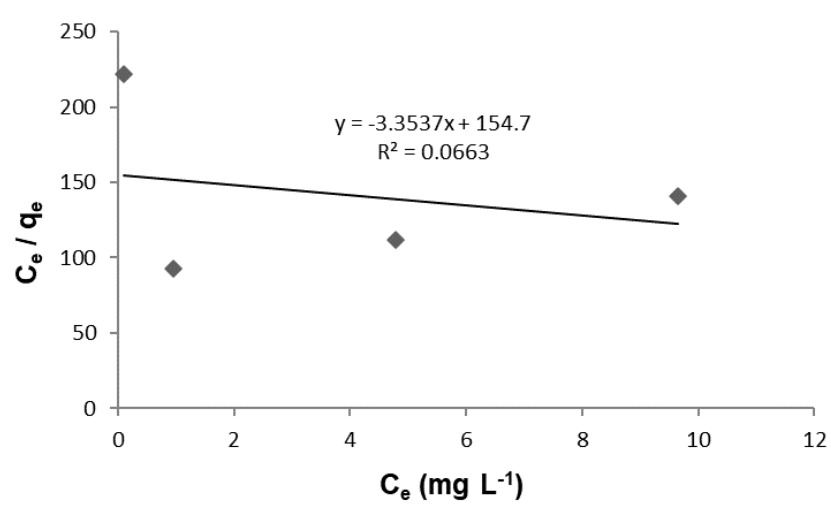

Fig. 17. Linearization of the graph of maximum adsorption capacity, applying to the Langmuir model.

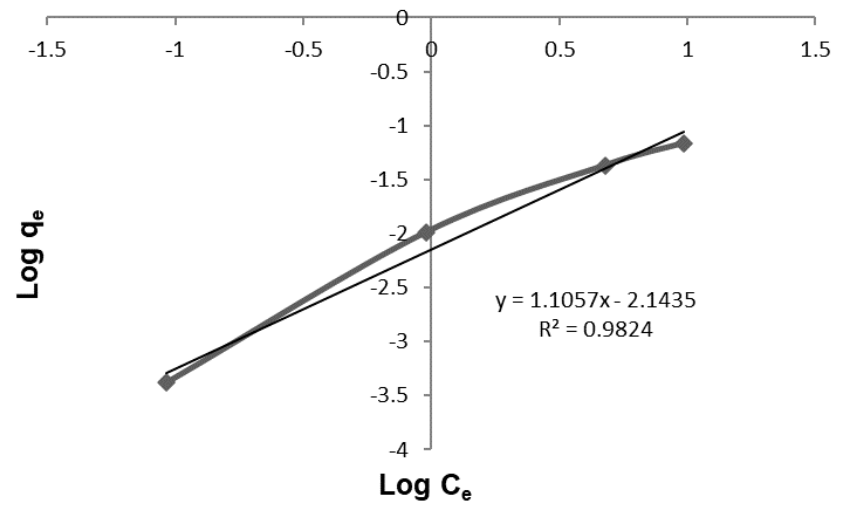

Fig. 18. Linearization of the graph of maximum adsorption capacity, applying to the Freundlich model.

From the Langmuir isotherm, it can be seen that the model is not properly described, since the correlation coefficient $\left(\mathrm{R}^{2}\right)$ is low (Table IV) and the value of the slope is negative. This parameter indicates that, if there is heterogeneity on the surface, both the pores of the adsorbent and the surface will influence the adsorption [97].

The Freundlich constant and the correlation values were also shown in Table V.

TABLE V: PARAMETERS OBTAINED USING THE LANGMUIR AND FREUNDLICH EQUATIONS FOR THE CHLORAMPHENICOL ANALYTE

\begin{tabular}{cccccc}
\hline & Langmuir & \multicolumn{4}{c}{ Freundlich } \\
\hline & $\begin{array}{c}\mathrm{q}_{\mathrm{e}}(\exp )^{*} \\
\left(\mathrm{mg} \cdot \mathrm{g}^{-1}\right)\end{array}$ & $\mathrm{R}^{2}$ & $\begin{array}{c}\mathrm{K}_{\mathrm{F}}(\mathrm{cal})^{* *} \\
\left(\mathrm{mg} \cdot \mathrm{g}^{-1}\right)\end{array}$ & $\mathrm{n}$ & $\mathrm{R}^{2}$ \\
\hline Chloramphenicol & 0.0103 & 0.0663 & 0.0072 & 0.9044 & 0.9824 \\
\hline * experimental; ** calculated. & & & &
\end{tabular}

When applying the linearization of the Freundlich model (Fig. 18), it was observed that the adsorbent, when in contact with the compound under study, showed agreement with the correlation coefficient, indicating that the data fit better to this model.

For the Freundlich model, the $\mathrm{K}_{\mathrm{F}}$ value is related to the adsorption capacity while the $\mathrm{n}$ value indicates the intensity of the adsorption, that is, whether it is favorable or not, as well as indicating the distribution of the adsorption sites as your energy. Since the value of $\mathrm{n}$ is less than 1 , this indicates that highly energetic sites are not occupied by less energetic ones. When analyzing the two factors, it is possible to verify that the adsorption process occurs in multiple layers. In addition, the value of $1 / \mathrm{n}$ indicates the heterogeneity of the adsorbent surface, the closer to zero, the more heterogeneous the surface. The low $\mathrm{K}_{\mathrm{f}}$ value indicates small adsorption of the compound, as well as the good linearity indicates that the adsorbent-adsorbate interaction can be of a physical nature [98].

\section{Alternative Tests}

In order to address data complementary to the project and try to increase the efficiency of removing the leaves of cattail, experiments were carried out with the following conditions in triplicate: cattail chemically treated with $\mathrm{NaOH} 0.1 \mathrm{~mol} \cdot \mathrm{L}^{-1}$; continuous flow system; in addition to cattail activated carbon (Table VI). It was made available in APPENDIX 4A, only the chromatogram referring to the drug control group in the concentration $1 \mathrm{mg} \cdot \mathrm{L}^{-1}$ and $\mathrm{pH}$ close to 6.0 , as well as the comparison with cattail activated carbon, after adsorption, due to its higher percentage value removal (APPENDIX 4B). 


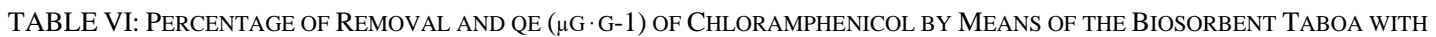

\begin{tabular}{ccccc}
\multicolumn{5}{c}{ ALTERNATIVE TREATMENTS } \\
\hline Material & Mass $(\mathrm{mg})$ & Removal $(\%)$ & $\mathrm{q}_{\mathrm{e}}\left(\mu \mathrm{g} \cdot \mathrm{g}^{-1}\right)$ & R.S.D. $(\%)$ \\
\hline Cattail with NaOH & 100.6 & 5.5143 & 10.9798 & 0.2288 \\
Cattail in flow & 10.8 & 8.2502 & 153.0190 & 0.4606 \\
Activated carbon of cattail & 100 & 55.8384 & 125.8933 & 2.5712 \\
\hline
\end{tabular}

The methodology of reference [99] was applied to make the chemical treatment with $\mathrm{NaOH}$. In Table VI, it can be seen that there was no significant difference between removal by fresh cattail and cata treated with $\mathrm{NaOH}$.

While, in order to carry out the experiment in continuous flow, the following procedure was carried out: packing the column in Tygon tube, containing $10 \mathrm{mg}$ of the material; then $20 \mathrm{ml}$ of the chloramphenicol solution $\left(1 \mathrm{mg} \cdot \mathrm{L}^{-1}\right)$ were percolated, at $2 \mathrm{ml} \cdot \mathrm{min}^{-1}$, and samples of 10,30 and 60 minutes were analyzed. It was found that the removal was greater than that of the cattail in a batch system, while the high $\mathrm{q}_{\mathrm{e}}$ reflects the low amount of material used.

The activated carbon of cattail was used for being a material of easy obtaining and processing, being constituted by chemical groups that favor the adsorption of contaminants, besides presenting and high surface area. Looking at Table VI, it is clear that the activated carbon of cattail, following the same conditions as the preliminary tests of the cattails biosorbent in natura, presented the most significant removal percentage.

\section{CONCLUSIONS}

When analyzing the cellulose-based polymeric biosorbent (cattail), the presence of viable chemical elements and groups was verified for adsorption to occur, as detected in the FTIR and NMR graphs, in addition to the elemental analysis data of nitrogen and sulfur. The raw material presented low surface area, being typical of non-porous materials or with a predominance of meso and macropores. Besides these characteristics, it also has a heterogeneous surface that contributes to the adsorption of drugs by physisorption. As for the batch tests, it can be concluded, therefore, that it is necessary to undergo other treatments or techniques to be used as a biosorbent to adsorb organic contaminants, among which, antibiotics, its effectiveness being proven in the studies on activated carbon. Thereby, in addition to presenting a relevant sustainable motive, by taking advantage of a vast biosorbent in nature, it also represents an alternative to promote the decontamination of water resources polluted by emerging contaminants. Therefore, it would be interesting to apply the biosorbent in natura and / or its activated carbon, in aerated tanks in WTPs, under controlled conditions, to remove chloramphenicol in real effluent samples for later quantification by UPLC.

APPENDIX

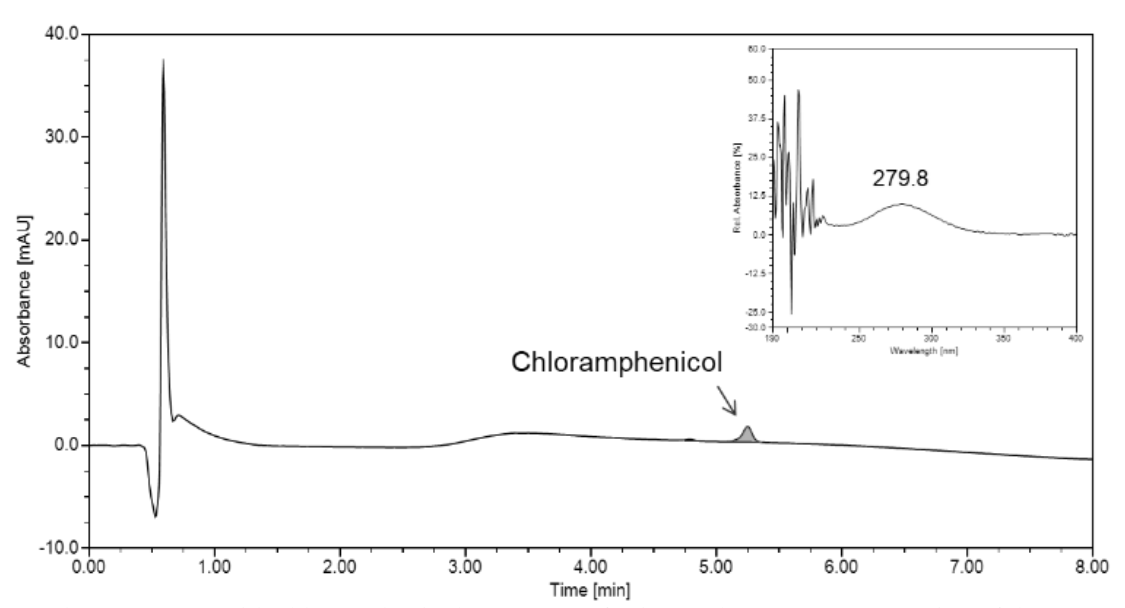

Fig. 19. Chromatogram with chloramphenicol spectrum referring to the curve concentration of the compound, containing $0.1 \mathrm{mg} \cdot \mathrm{L}^{-1}$ at $\mathrm{pH} \pm 6.0$ and $\lambda=277 \mathrm{~nm}$. 
European Journal of Advanced Chemistry Research www.ej-chem.org

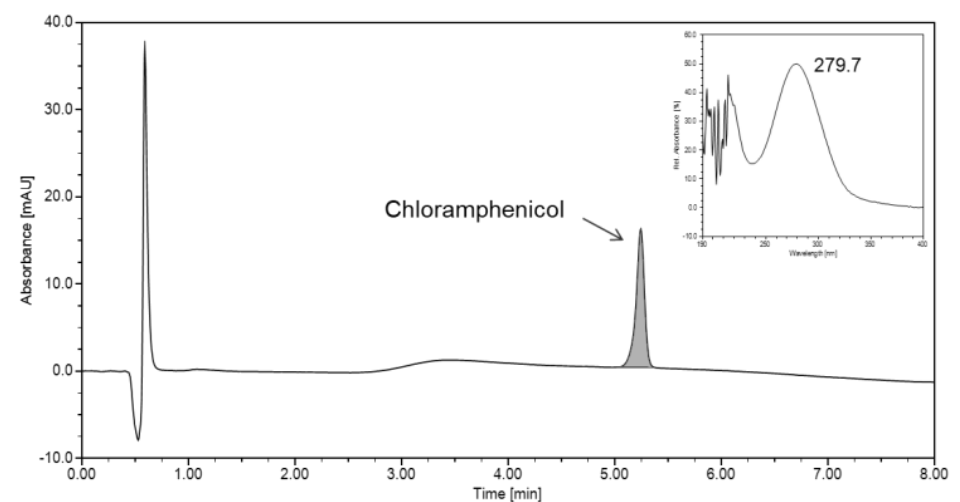

Fig. 20. Chromatogram with chloramphenicol spectrum referring to the curve concentration of the compound, containing $1.0 \mathrm{mg} \cdot \mathrm{L}^{-1}$ at $\mathrm{pH} \pm 6.0$ and $\lambda=277 \mathrm{~nm}$.

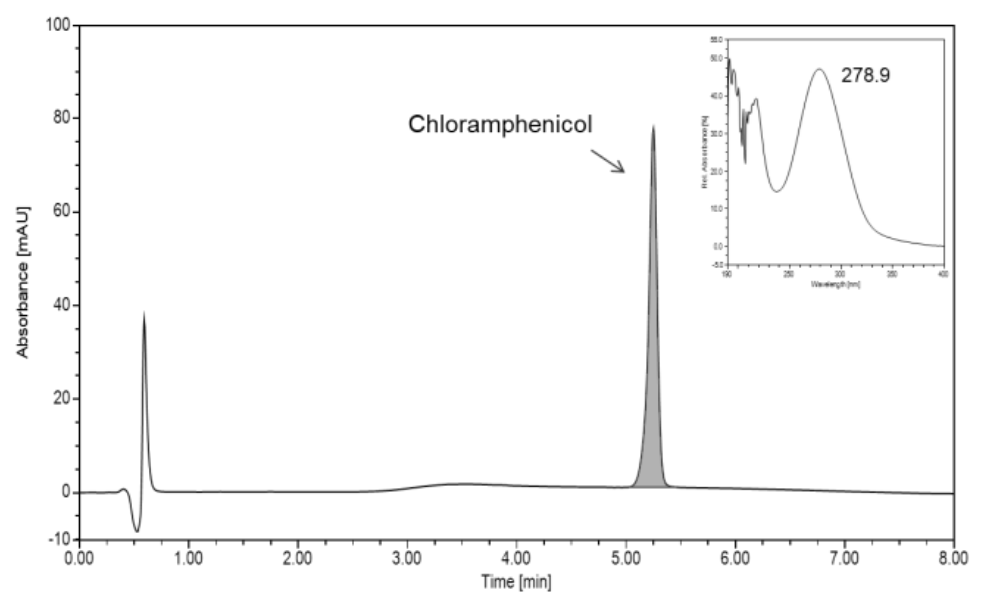

Fig. 21. Chromatogram with chloramphenicol spectrum referring to the curve analysis of the compound, containing $5.0 \mathrm{mg} \cdot \mathrm{L}^{-1}$ at $\mathrm{pH} \pm 6.0$ and $\lambda=277 \mathrm{~nm}$.

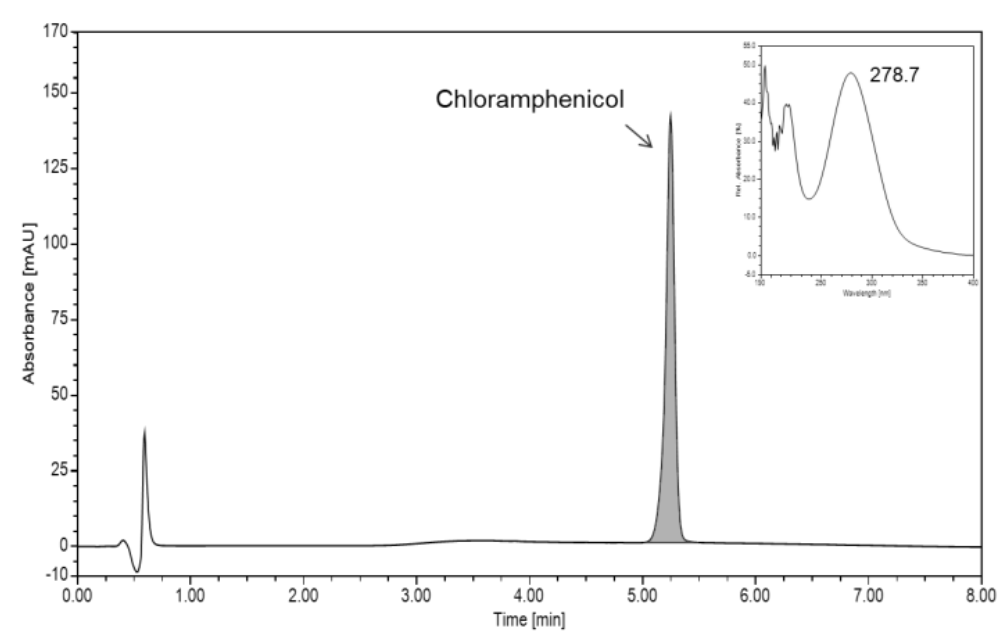

Fig. 22. Chloramphenicol spectrum chromatogram referring to the curve concentration of the compound, containing $10.0 \mathrm{mg} \cdot \mathrm{L}^{-1}$ at $\mathrm{pH} \pm 6.0$ and $\lambda=277 \mathrm{~nm}$.

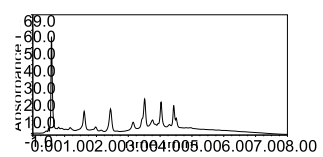

Fig. 23. Chromatogram referring to the white group, containing the peaks of biosorbent Typha angustifolia L., cattail, in ultrapure water at $\mathrm{pH} \pm 6.0$ and $\lambda=278 \mathrm{~nm}$. 
European Journal of Advanced Chemistry Research www.ej-chem.org

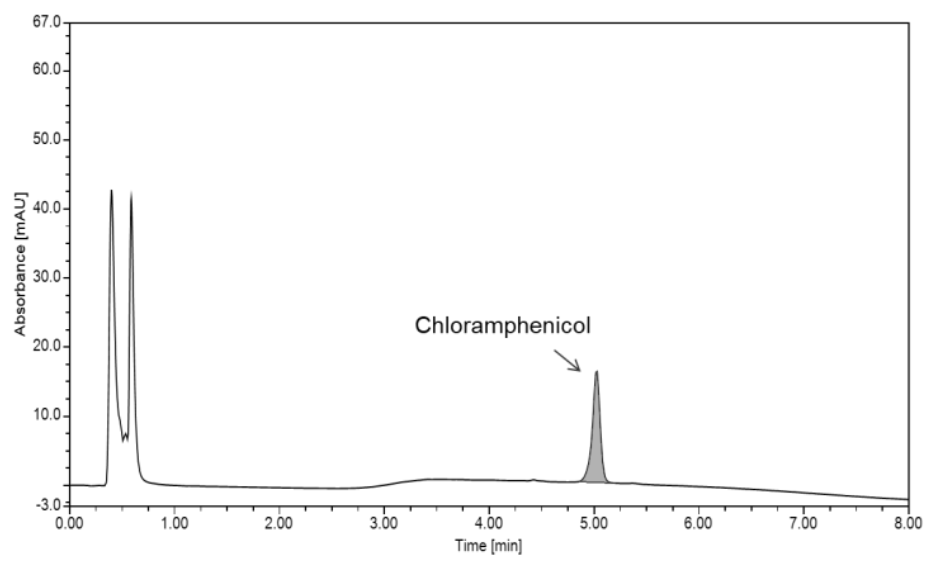

Fig. 24. Chromatogram referring to the control group, containing the drug chloramphenicol in ultrapure water at $\mathrm{pH} \pm 6.0$ and $\lambda=278 \mathrm{~nm}$.

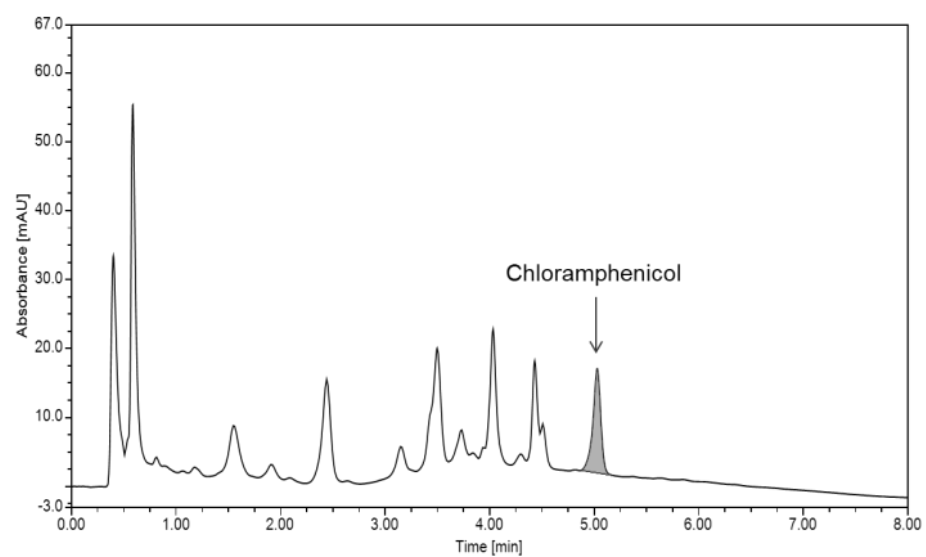

Fig. 25. Chromatogram referring to the sample group, containing both the biosorbent, as the drug in ultrapure water at $\mathrm{ph} \pm 6.0$ and $\lambda=278 \mathrm{~nm}$.

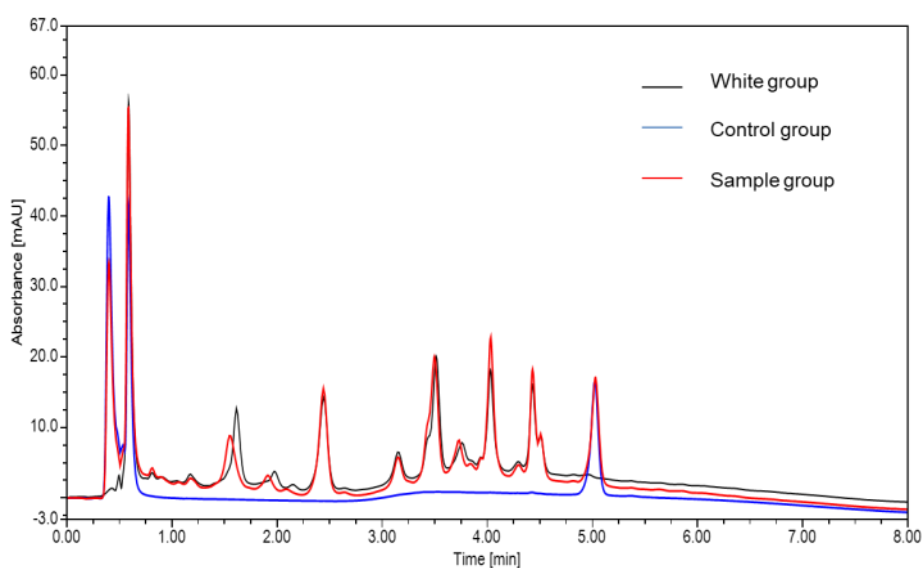

Fig. 26. Chromatogram comparing the different test groups preliminaries at $278 \mathrm{~nm}$.

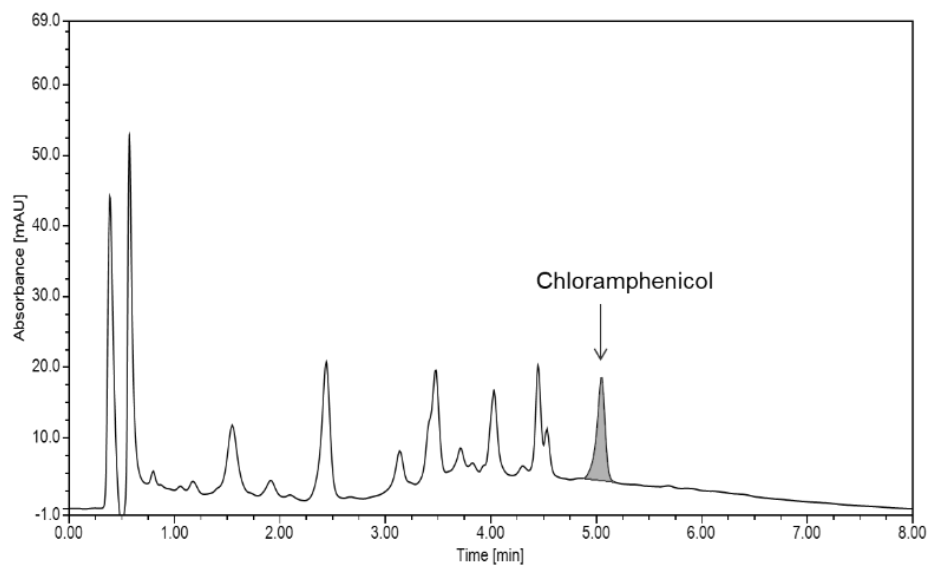

Fig. 27. Chromatogram referring to the adsorption of the drug after maximum capacity, comprising an initial concentration of $1.0 \mathrm{mg} \cdot \mathrm{L}^{-1}$ of the analyte, after 24 hours, at $\mathrm{pH} \pm 6.0$ and $\lambda 278 \mathrm{~nm}$. 


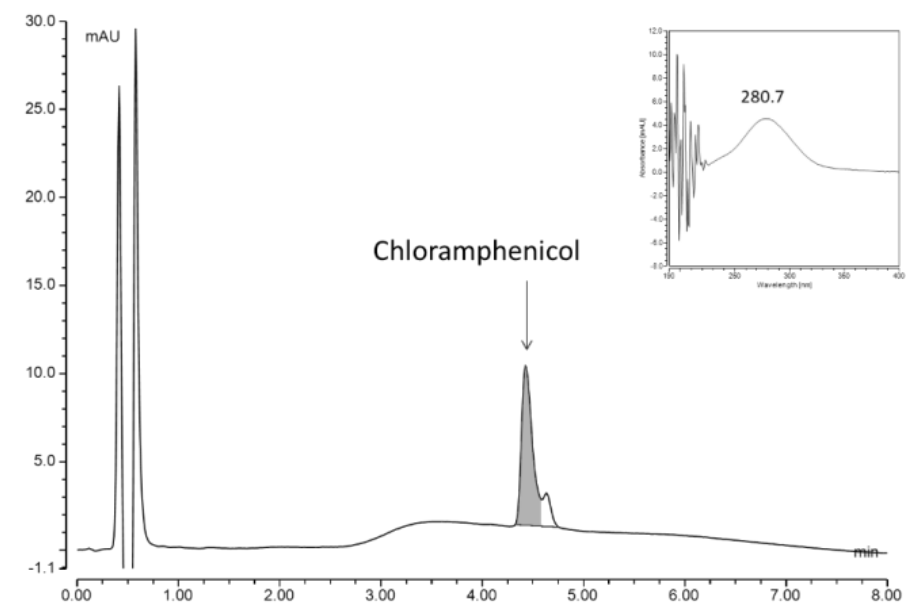

Fig. 28. Chromatogram referring to the control group, containing the drug chloramphenicol $\left(1.0 \mathrm{mg} \cdot \mathrm{L}^{-1}\right)$ in ultrapure water at $\mathrm{pH} \pm 6.0$ and $\lambda=278 \mathrm{~nm}$ for the tests with cattail activated carbon.

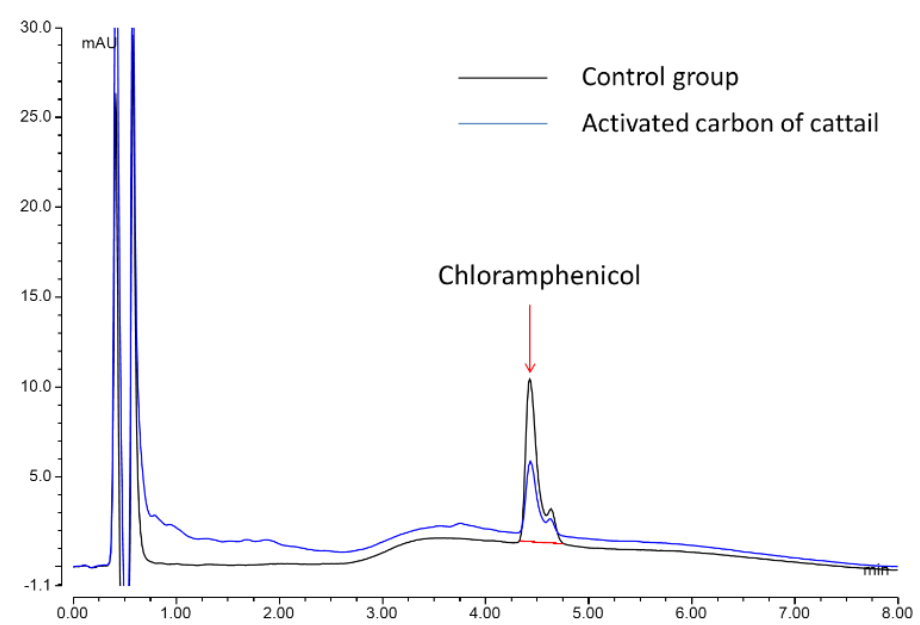

Fig. 29. Comparative chromatogram between the control group $\left(1.0 \mathrm{mg} \cdot \mathrm{L}^{-1}\right)$ and the removal of chloramphenicol by activated charcoal from cattail at $\mathrm{pH} \pm 6.0$ and $\lambda=278 \mathrm{~nm}$.

\section{ACKNOWLEDGMENT}

Authors gratefully thank the Department of Chemical and Biological Sciences from São Paulo State University (UNESP), Botucatu, for the assistance during this study. Authors thank Fapesp and CNPq for the financial support (Fapesp: 2012/21795-9, 2012/21795-9, 15/04791-8 and 2018/18787-0; CNPq: $310043 / 2018-2)$.

\section{REFERENCES}

[1] J. C. Rocha, and R. N. Hirche. Determinação de metais totais e metais solúveis em amostras de água bruta e água tratada de represas de captação da estação de tratamento de águas (ETA) de Araraquara-SP. Eclética Química, São Paulo, 1994;19:105117.

[2] M. L. Zuccari. Determinação de fatores abióticos e bióticos do Ribeirão Lavapés BotucatuSP. 113 f. Dissertação (Mestrado) - Faculdade de Ciências Agronômicas, Universidade Estadual Paulista Julio de Mesquita Filho, Botucatu, 1991.

[3] S. Rodriguez-Mozaz, M. J. Lopez de Alda, D. Barceló. Picogram per liter level determination of estrogens in natural waters and waterworks by a fully automated on-line solid phase extraction-liquid chromatography-electrospray tandem mass spectrometry method. Analytical Chemistry, 2004;76(23):6998-7006.

[4] R. W. Reis Filho, R. Luvizotto-Santos, E. M. Vieira. Poluentes Emergentes como Desreguladores Endócrinos. Journal of The Brazilian Society of Ecotoxicology, 2007;2:283-288.

[5] C. G. A. Da Silva, and C. H. Collins. Aplicações de cromatografia líquida de alta eficiência para o estudo de poluentes orgânicos emergentes. Química Nova, 2011;34(4):665.

[6] J. A. Bendassolli, G. A. Tavares, , R. F. Ignoto, A. L. R. M. Rosset. Procedimentos para recuperação de Ag de resíduos líquidos e sólidos. Química Nova, 2003;26(4):578-581.

[7] P. Ashtari, K. Wang, X. Yang, S. Huang, Y. Yamini. Novel separation and preconcentration of trace amounts of copper(II) in water samples based on neocuproine modified magnetic microparticles. Analytica Chimica Acta, 2005;550(1-2):18-23.

[8] K. M. Dimpe, J.C. Ngila, P.N. Nomngongo. Preparation and application of a tyre-based activated carbon solid phase. Physics and Chemistry of the Earth, 2018;105:161-169.

[9] ANVISA. Agência Nacional de Vigilância Sanitária. Resolução RDC 306/04, 2005. Available: http://elegis.anvisa.gov.br/leisref/public/showAct.php?id=13554.

[10] R. L. Z. Cavalcanti, G. M. S. Lima, M. C. Silva, R. P. Scelza, V. R. Moura, V. R. Leite. Descarte Domiciliar de Medicamentos. Revista Presença, 2015;1(2):56-77.

[11] I. Oller, S. Malato, J. A. Sánchez-Pérez. Combination of Advanced Oxidation Processes and biological treatments for wastewater decontamination - A review. Science of the Total Environment, v. In Press, Corrected Proof, 2010. 
[12] D. M. Bila, and M. Dezotti. Fármacos no meio ambiente. Química Nova, São Paulo, 2003;26(4):523-530.

[13] T. Heberer. Occurrence, fate, and removal of pharmaceutical residues in the aquatic environment: a review of recent research data. Toxicology Letters, 2002;131(1-2):5-17.

[14] E. S. Gil, and R. O. Mathias. Chemical pharmaceutical wastes: classification and risks. Revista Eletrônica de Farmácia, 2005;2(2):87-93.

[15] B. Halling-Sørensen, N. N. Nielsen, P. F. Lanzky, F. Ingerslev, H. C. H. Lutzhoft, S. E. Jørgensen. Occurrence, Fate and effects of pharmaceutical substances in the Environment - A review. Chemosphere, 1998;36(2):357-393.

[16] MINISTÉRIO DO MEIO AMBIENTE, Resolução CONAMA $\mathrm{n}^{\circ} 430$, de 13 de maio de 2011. Available: http://www.mma.gov.br/port/conama/res/res11/res43011.pdf.

[17] C. D. Miranda, and R. Zemelman. Bacterial resistance to oxytetracycline in Chilean salmon farming. Aquaculture, 2002;212:31-47.

[18] G. R. Boyd, H. Reemtsma, D. A. Grimm, S. Mitra. Pharmaceutical and personal care products (PPCPs) in surface and treated waters of Louisiana, USA and Ontario, Canada. Science of The Total Environment, 2003;311:135-149.

[19] T. A. Ternes, M. Meisenheimer, D. Mcdowell, F. Sacher, H. J. Brauch, B. Haist-Gulde, G. Preuss, U. Wilme, N. Zulei-Seibert. Removal of pharmaceuticals during drinking water treatment. Environmental Science and Technology, 2002;36:3855-3863.

[20] M. Schriks, M. B. Heringa, M. M. E. Van der Kooi, P. Voogt, A. P. Van Wezel. Toxicological relevance of emerging contaminants for drinking water quality. Water Research, 2010;44: 461.

[21] E. J. Barreiro. Sobre a química dos remédios, dos fármacos e dos medicamentos. Cadernos Temáticos de Química Nova na Escola, 2001;3: 4-9.

[22] H. J. Smith. Introduction to the principles of drug design and action. Boca Raton: Taylor \& Francis Group, 2006:684-720.

[23] K. Kummerer. Drugs in the environment: emission of drugs, diagnostic aids and disinfectants into wastewater by ecological indicators, Review of 1-13 hospitals in relation to other sources. Chemosphere, 2001;45:957-969.

[24] H. S. Spinosa, S. L. Górniak, M. M. Bernardi. Farmacologia aplicada à medicina veterinária. Rio de Janeiro: Guanabara Koogan, 2006, 897 pp.

[25] The Extra Pharmacopoeia, martindale, 29th ed., London: The Pharmaceutical Press, 1989, 769 pp.

[26] K. Ajit, A. K. Sarmah, M. T. Meyer, A. B. A. Boxall. A global perspective on the use, sales, exposure pathways, occurrence, fate and effects of veterinary antibiotics (VAs) in the environment. Chemosphere, 2006;65(5):725-759.

[27] L. G. P. Rezende, V. M. Prado, R. S. Rocha, A. A. G. F. Beati, M. P. T. Sotomayor, M. R. V. Lanza. Degradação eletroquímica do cloranfenicol em reator de fluxo. Quimica Nova, 2010;33(5):1088-1092.

[28] F. Zeegers, M. Gibella, B. Tilquin. Analysis of some products from the irradiation of solid chloramphenicol. Radiation Physics and Chemistry, 1997;50(2):149-153.

[29] X. Peng, J. Tan, C. Tang, Y. Yu, Z. Wangtt. Multiresidue determination of fluoroquinolone, sulfonamide, trimethoprim, and chloramphenicol antibiotics in urban waters in China. Environmental Toxicology and Chemistry, 2008;27(1):73-79.

[30] X. Peng, Z. Wang, W. Kuang, T. Jianhua, L. Ken. A preliminary study on the occurrence and behavior of sulfonamides, ofloxacin and chloramphenicol antimicrobials in wastewaters of two sewage treatment plants in Guangzhou, China. Science of the Total Environment, 2006;37:314-322.

[31] K. Choi, Y. Kim, J. Jung, M. H. Kim, C. S. Kim, N. H. Kim, J. Park. Occurrences and ecological risks of roxithromycin, trimethoprim, and chloramphenicol in the Han River, Korea. Environmental Toxicology and Chemistry, 2008;27(3):711-719.

[32] H. Liu, G. P. Zhang, C. Q. Liu, L. Li, M. Xiang. The occurrence of chloramphenicol and tetracyclines in municipal sewage and the Nanming River, Guiyang City, China. Journal of Environmental Monitoring, 2009;11(6):1199-1205.

[33] Y. Xu, F. Luo, A. Pal, K. Y. H. Gin, M. Reinhard. Occurrence of emerging organic contaminants in a tropical urban catchment in Singapore. Chemosphere, 2011:83(7):963-969.

[34] K. N. Woodward. Pesticide, Veterinary and Other Residues in Food. In: Watson, D. H., ed.; Cambridge: Woodward Publisher Limited, 2004, ch. 8, pp. 176.

[35] ANVISA, Antimicrobianos - Bases Teóricas e Uso Clínico (Cloranfenicol). Available: http://www.anvisa.gov.br/servicosaude/controle/rede_rm/cursos/rm_controle/opas_web/modulo1/cloranfenicol6.htm.

[36] EEC - COUNCIL REGULATION No2377/90 - Laying down a Community procedure for establishment of maximum residue limits of veterinary medicinal products in foodstuffs of animal origin. Official Journal of the European Community. L224, 1990.

[37] M. C. Rebstock, H. M. Crooks Jr, J. Controulis, Q. R. Bartz. Chloramphenicol (Chloromycetin). Journal of American Chemical Society, 1949;71:2458-2462.

[38] SIGMA. Chloramphenicol. Product
https://www.sigmaaldrich.com/content/dam/sigmaaldrich/docs/Sigma/Product_Information_Sheet/c0378pis.pdf.
[39] BRASIL. Ministério da Saúde. ANVISA. Resolução RDC n ${ }^{\circ}$. 306, de 07 de dezembro de 2004. Dispõe sobre o Regulamento Técnico para o gerenciamento de resíduos de serviços de saúde. Available: http://portal.anvisa.gov.br/documents/33880/2568070/res0306_07_12_2004.pdf.

[40] BRASIL. Conselho Federal de Farmácia. CFF. Resolução RDC n 33, de 25 de fevereiro de 2003. Dispõe sobre o Regulamento Técnico para o gerenciamento de resíduos de serviços de saúde. Available: http://www.cff.org.br/userfiles/file/resolucao_sanitaria/33.pdf.

[41] D. W. Kolpin, E. T. Furlog, M. T. Meyer, E. M. Thurman, S. D. Zaugg, L. B. Barber, H. T. Buxton. Pharmaceuticals, hormones, and other organic wastewater contaminants in U.S. streams, 1999-2000: a national reconnaissance. Environmental Science and Technology, 2002;36:1202.

[42] K. Sun, Y. Shi, W. Xu, N. Potter, Z. LI, J. Zhu. Modification of clays and zeolites by ionic liquids for the uptake of chloramphenicol from water. Chemical Engineering Journal, 2017;313:336-344.

[43] A. Mulroy, "When the cure is the problem", Water Environment \& Technology, 2001;13(2):32-37.

[44] T. A. Ternes, M. Stumpf, J. Mueller, K. Haberer, R. D. Wilken, M. Servos. Behavior and occurrence of estrogens in municipal sewage treatment plants - I. Investigations in Germany, Canada and Brazil. Science of the Total Environment, 1999;225:8190.

[45] Stumpf M.; Ternes T.A.; Wilken R.; Rodrigues S.V.; Baumann W. Polar drug residues in sewage and natural waters in the state of Rio de Janeiro, Brazil. Science of the Total Environment, 1999;225:135.

[46] E. Martínes-Carbalho, C. González-Barreiro, S. Scharf, O. Gans. Environmental monitoring study of selected veterinary antibiotics in animal manure and soils in Austria. Environmental Pollution, 2007;148:570-579.

[47] R. Hirsch, T. Ternes, K. Haberer, K. L. Kratz. Occurrence of antibiotics in the aquatic environment. Science of the Total Environment, 1999;225:109-118.

[48] E. Kaale, M. Chambuso, J. Kitwala. Analysis of residual oxytetracycline in fresh milk using polymer reversed-phase column. Food Chemistry, 2008;107:1289-1293.

[49] Q. Wang, Q. Liu, J. Li. Tissue distribution and elimination of oxytetracycline perch Lateolabras janopicus and black seabream (Sparus macrocephalus) following oral administration. Aquaculture, 2004;237:31-40.

[50] C. Adams, Y. Wang, K. Loftin, M. Meyer. Removal of antibiotics from surface and distilled water in conventional water treatment processes. Journal of Environmental Engineering, 2002;128(3):253-260. 
[51] J. Ding, Q. Li, X. Xu, X. Zhang, Y. Su, Q. Yue, B. Gao. A wheat straw cellulose-based hydrogel for Cu (II) removal and preparation copper nanocomposite for reductive degradation of chloramphenicol. Carbohydrate polymers, 2018;190:12-22.

[52] I. A. Ricardo, V. A. Paiva, C. E. Paniagua, A. G. Trovó. Chloramphenicol photo-Fenton degradation and toxicity changes in both surface water and a tertiary effluent from a municipal wastewater treatment plant at near-neutral conditions. Chemical Engineering Journal, 2018;347:763-770.

[53] M. B. Ahmed, J. L. Zhou, H. H. Ngo, W. Guo, M. A. H. Johir, D. Belhaj. Competitive sorption affinity of sulfonamides and chloramphenicol antibiotics toward functionalized biochar for water and wastewater treatment. Bioresource technology, 2017;238:306-312.

[54] T. Yao, and S. Yao. Magnetic ionic liquid aqueous two-phase system coupled with high performance liquid chromatography: A rapid approach for determination of chloramphenicol in water environment. Journal of Chromatography A, 2017;1481:1222.

[55] R. F. Nascimento, A. C. A. Lima, C. B. Vidal, D. Q. Melo, G. S. C. Raulino. Cinética de adsorção. In: teóricos e aplicações ambientais. Fortaleza: Imprensa Universitária, 2014, pp. 256.

[56] D. M. Ruthven. Principle of Adsorption and Adsorption Processes. New York: John Wiley \& Sons, 1984, ch. 2-3, pp. 433.

[57] D. D. Do. Adsorption analysis: equilibria and kinetics., 2 ed. London: Imperial college press, 1998, pp. 1-18.

[58] A. Dąbrowski. Adsorption - from theory to practice. Advances in Colloid and Interface Science, 2001;93(1-3):135-224.

[59] A. W. Adamson, and A. P. Gast. Adsorption of gases and vapors on solids. Physical chemistry of surfaces, 1997:591-681.

[60] H. Lingeman, and S.J.F.H. Oussoren. Particle-loaded membranes for sample concentration and/or clean up in bioanalysis. Journal of Chromatography B, 1997;689:221-237.

[61] G. R. Castro, I. L. Alcântara, P. S. Roldan, D. F. Bozano, P.M. Padilha, A. O. Florentino, J. C. Rocha. Synthesis, characterization and determination of the metal ions adsorption capacity. Materials Research, 2004;7(2):329-334.

[62] J. L. Sotelo, A. Rodríguez, S. Álvarez, J. García. Removal of caffeine and diclofenac on activated carbon in fixed bed colum. Chemical Engineering Research and Design, Amsterdam, 2012;90(7):967-974.

[63] S. M. Evangelista, E. Deoliveira, G. R. Castro, L. F. Zara, A. G. S. Prado. Hexagonal mesoporous silica modified with 2mercaptothiazoline for removing mercury from water solution. Surface Science, 2007;601:2194-2202.

[64] A. S. Mestre, J. Pires, J. M. Nogueira, J. B. Parra, A. P. Carvalho, C. O. Ania. Waste-derived activated carbons for removal of ibuprofen from solution: Role of surface chemistry and pore structure. Bioresource Technology, Amsterdam, 2009;10(5):1720-1726.

[65] A. P. S. Immich. Remoção de corantes de efluentes têxteis utilizando folhas de Azadirachta indica como adsorvente. 119 pp, Dissertação (Mestrado em Engenharia Química) - Departamento de Engenharia Química e Engenharia de Alimentos, Universidade Federal de Santa Catarina, Florianópolis, 2006.

[66] E. S. Brito, S. A. Moreira, R. F. Nascimento, A. G. Oliveira, F. W. Sousa. Remoção de metais de solução aquosa usando bagaço de caju. Química Nova, 2009;32(7):1717-1722.

[67] B. Royer, N. F. Cardoso, E. C. Lima, J. C. P. Vaghetti, N. M. Simon, T. Calvete, R. C. Veses. Applications of Brazilian pinefruit Shell in natural and carbonized forms as adsorbents to removal of methylene blue from aqueous solutions - kinetic and equilibrium study. Journal of Hazardous Materials, 2009;164:1213-1222.

[68] R. Gong, Y. Ding, M. Li, C. Yang, H. Liu, Y. Sun. Utilization of powdered peanut hull as biosorbent for removal of anionic dyes from aqueous solution. Dyes and Pigments, 2005;64:187-192.

[69] S. Albertini, L. F. Carmo, L. G. Prado-Filho. Elimination of dyes from aqueous solutions using iron oxides and chitosan as adsorbents. A comparative study. Quimica Nova, 2009;32(5):1239-1244.

[70] V. Prigione, G. C. Varese, L. Casieri, V. F. Marchisio. Biosorption of simulated dyed effluents by inactivated fungal biomasses. Bioresource Technology, 2008;99:3559-3567.

[71] G. Bonanno, and G. L. Cirelli. Comparative analysis of elemento concentrations and translocation in three wetland congener plants: Typha latifólia and Typha angustifólia. Ecotoxology and Environmental Safety, 2017;143:92-101.

[72] C. S. Oliveira, and F. Petacci. Cinética de decomposição da macrófita Typha angustifolia L. presented at CONGRESSO DE PESQUISA, ENSINO E EXTENSÃO, VI. Goiânia. Anais do VI Congresso de Pesquisa, Ensino e Extensão, pp. 2976-2988, 2009.

[73] D. Demirezen, and A. Aksoy. Accumulation of heavy metals in Typha angustifolia (L.) and Potamogeton pectinatus (L.) living in Sultan Marsh (Kayseri, Turkey). Chemosphere, 2004;56:685-696.

[74] R. A. Almeida, L. F. C. Oliveira, H. J. Kliemann. Eficiência de espécies vegetais na purificação de esgoto sanitário. Pesquisa Agropecuária Tropical, 2007;37:1-9.

[75] P. A. R. D. Sousa. Avaliação da adsorção de contaminantes emergentes pela Casca de Banana e Folhas da Typha angustifolia L., 117 pp. Dissertação de Mestrado (PósGraduação em Química da Universidade Federal de Goiás-Regional Catalão), 2015.

[76] G. F. Pang. Chloramphenicol. In___: Analytical Methods for Food Safety by Mass Spectrometry: Veterinary Drugs (Volume II). London: Academic Press, 2018, ch. 4, pp. 123-141.

[77] S. Lagergren. About Theory of So-Called Adsorption of Soluble Substances. Kungl. Svenska vetenskapsakademiens handlingar, 1898;24:1.

[78] Y. S. Ho, and G. Mckay. Pseudo-second order for the sorption process. Process Biochemistry, 1999;34:451-465.

[79] T. R. Gonçalves. Adsorção de Cu II em lignina e celulose obtidos a partir de resíduos agrícolas. 63 pp., MONOGRAFIA. Universidade Tecnológica Federal do Paraná, Campo Mourão, 2015.

[80] A. S. Silva. Avaliação da capacidade de remoção de saxitoxinas por diferentes tipos de carvão ativado em pó produzidos no Brasil. 115 pp., Dissertação (Mestrado em Tecnologia Ambiental e Recursos Hídricos) - Faculdade de Tecnologia, Universidade de Brasília, Brasília, 2005.

[81] J. L. Tambosi. Remoção de fármacos e avaliação de seus produtos de degradação através de tecnologias avançadas de tratamento. 140 pp, Tese (Doutorado em Engenharia Química) - Departamento de engenharia Química, Universidade Federal de Santa Catarina, Florianópolis, 2008.

[82] V. Ponnusami, K. S. Rajan, S. N. Srivastava. Application of film-pore diffusion model for methylene blue adsorption onto plant leaf powders. Chemical Engineering Journal, Amsterdam, 2010;163(3):236-242.

[83] C. H. Bolster, and G. M. Hornberger. On the Use of Linearized Langmuir Equations. Soil Science Society of America Journal, 2006;71:1796-1806.

[84] J. Febrianto, A. N. Kosasih, J. Sunarso, Y. H. Ju, N. Indraswati, S. Ismadji. Equilibrium and kinetic studies in adsorption of heavy metals using biosorbent: A summary of recent studies. Journal of Hazardous Materials, 2009;162:616-645.

[85] N. A. Qambrani, M. M. Rahman, S. Won, S. Shim, C. Ra. Biochar properties and ecofriendly applications for climate change mitigation, waste management, and wastewater treatment: A review. Renewable and Sustainable Energy Reviews, 2017;79:255-273.

[86] J. Vella, F. Busuttil, N. S. Bartolo, C. Sammut, V. Ferrito, A. Serracinoinglott, L. Azzopardi, G. Laferla. A simple HPLC-UV method for the determination of ciprofloxacin in human plasma. Journal of Chromatography B, 2015;989:80-85.

[87] A. O. Jorgetto, A. C. P. Silva, M. H. P. Wondracek, R. I. V. Silva, E. D. Velini, M. J. Saeki, V. A. Pedrosa, G. R. Castro. Multilayer adsorption of $\mathrm{Cu}(\mathrm{II})$ and $\mathrm{Cd}(\mathrm{II})$ over Brazilian Orchid Tree (Pata-de-vaca) and its adsorptive properties. Applied Surface Science, 2015;345:81-89. 
[88] E. N. Ali, S. R. Alfarra, M. M. Yusoff, M. F. Rahman. Environmentally friendly biosorbent from Moringa Oleifera leaves for water treatment. International Journal of Environmental Science and Development, 2015;6:165-169.

[89] M. Bendjelloul, E. H. Elandaloussi, L. C. Ménorval, A. Bentouami. Quaternized triethanolamine-sebacoyl moieties in highly branched polymer architecture as a host for the entrapment of acid dyes in aqueous solutions. Journal of Water Reuse and Desalination, 2017;7(1):53-65.

[90] S. M. Anisuzzaman, C. G. Joseph, W. M. A. B. W. Daud, D. Krishnaiah, H. S. Yee. Preparation and characterization of activated carbon from Typha orientalis leaves. International Journal of Industrial Chemistry, 2015;6(1):9-21.

[91] L. J. Gibson. Inside Plants: An Engineering's View of the Arnold Arboretum. 2012, Harvard University. Available: http://arnoldia.arboretum.harvard.edu/pdf/articles/2012-70-2-inside-plants-an-engineer-s-view-of-the-arnold-arboretum.pdf.

[92] K. S. W. Sing, D. H. Everett, R. A. W. Haul, L. Moscou, R. A. Pirotti, J. Rouquerol, T. Siemieniewska. Reporting physisorption data for gas/solid systems with special reference to the determination of surface area and porosity (Recommendations 1984). Pure and applied chemistry, 1985;57(4):603-619.

[93] Q. Shi, J. Zhang, C. Zhang, C. LI, B. Zhang, W. Hu, J. T. Xu, R. Zhao. Preparation of activated carbon from cattail and its application for dyes removal. Journal of Environmental Sciences, 2010; 22(1):91-97.

[94] L. Ren, J. Zhang, Y. Li, C. L. Zhang. Preparation and evaluation of cattail fiber-based activated carbon for 2, 4-dichlorophenol and 2, 4, 6-trichlorophenol removal. Chemical Engineering Journal, 2011;168(2)553-561.

[95] Y. Guo, and D. A. Rockstraw. Physical and chemical properties of carbons synthesized from xylan, cellulose, and Kraft lignin by $\mathrm{H}_{3} \mathrm{PO}_{4}$ activation. Carbon, 2006;44(8): 1464-1475.

[96] H. Zhao, X. Liu, Z. Cao, Y. Zhan, X. Shi, Y. Yang, J. Zhou, J. Xu. Adsorption behaviour and mechanism of chloramphenicols, sulfonamides, and non-antibiotic pharmaceuticals on multi-walled carbon nanotubes. Journal of Hazardous Materials, 2016;310:235-245.

[97] D. A. Fungaro, J. C. Izidoro, M. Bruno. Aplicação de material zeolítico sintetizado de cinzas de carvão como adsorvente de poluentes em água. Eclética Química, São Paulo, 2009;34(1).

[98] C. R. G. Tavares, M. T. Veit, E. S. Cossich, S. M. Gomes-da-Costa, A. M. Gonzales. Isotermas de adsorção de cobre (II) sobre Biomassa fúngica morta, presented at Anais do IV Encontro Brasileiro sobre Adsorção - EBA, Rio de Janeiro - RJ, pp. 24$31,2003$.

[99] V. C. G. D. Santos, A. D. P. A. Salvado, D. C. Dragunski, D. N. C. Peraro, C. R. T. Tarley, J. Caetano. Highly improved chromium (III) uptake capacity in modified sugarcane bagasse using different chemical treatments. Química Nova, 2012;35(8):1606-1611. 